2 Virus Removal and Inactivation Mechanisms during Iron Electrocoagulation: Capsid and

4 Kyungho Kim ${ }^{1}$, Jothikumar Narayanan ${ }^{2}$, Anindito Sen $^{3}$, Shankararaman Chellam ${ }^{1,4}$

$5{ }^{1}$ Department of Civil \& Environmental Engineering, Texas A\&M University, College Station,

6 TX 77843-3136

$7 \quad{ }^{2}$ Centers for Disease Control and Prevention, National Center for Emerging and Zoonotic

8 Infectious Diseases, Atlanta, GA, 30329

$9 \quad{ }^{3}$ Microscopy and Imaging Center, Texas A\&M University, College Station, TX 77843-2257

$10{ }^{4}$ Department of Chemical Engineering, Texas A\&M University, College Station, TX 77843-3122

11 Corresponding author: S. Chellam, Zachry Department of Civil \& Environmental Engineering,

12 Texas A\&M University, College Station, TX 77843. Phone: (979) 458 5914; chellam@ tamu.edu

15 Numbers of Pages: 46

16 Numbers of Figures: 25

17 Numbers of Tables: 4 
18 Section S1. Phage Preparation, Enumeration, and Analysis. MS2 bacteriophage was purified

19 and concentrated in many steps. Escherichia coli was cultured in $10 \mathrm{~mL}$ tryptic soy broth solution

20 (TSB; Difco) at $37^{\circ} \mathrm{C}$ until reaching a mid-log phase. Next, $1 \mathrm{~mL}$ of the cultured E. coli suspension

21 was inoculated to $100 \mathrm{ml}$ of fresh TSB solution and cultured again at $37{ }^{\circ} \mathrm{C}$ until mid-log phase,

22 which was inoculated with MS2 at multiplicity of infection of 0.1 . After 16 hours of incubation,

23 the suspension was centrifuged at 13,500 g for $20 \mathrm{~min}$, subsequently filtered with $0.2 \mu \mathrm{m}$ and then

24 with a $0.1 \mu \mathrm{m}$ polyethersulfone (PES) syringe filter. The resulting filtrate was rinsed and

25 concentrated with phosphate buffer solution (PBS, $4.8 \mathrm{mM}$ of $\mathrm{NaH}_{2} \mathrm{PO}_{4}, 17.6 \mathrm{mM}$ of $\mathrm{Na}_{2} \mathrm{HPO}_{4}$,

$26145.4 \mathrm{mM}$ of $\mathrm{NaCl}, \mathrm{pH} 7.4 \pm 0.1$ ) using a $100 \mathrm{kDa}$ PES membrane centrifugal filter (Spin-X UF,

27 Corning) at 5,900 g for $20 \mathrm{~min}$ to remove soluble and low molecular weight impurities. ${ }^{1}$ MS2

28 retained on the membrane filter was resuspended in $1 \mathrm{~mL}$ of PBS and stored at $4{ }^{\circ} \mathrm{C}$. Infective

29 MS2 phages were quantified following double-agar layer method. ${ }^{1-3}$ The titer of final MS2 stock

30 was of the order of $10^{12} \mathrm{PFU} / \mathrm{mL}$. 
31 Section S2. Electrocoagulation. Prior to each experiment, the anode was scrubbed with a 220 grit

32 sandpaper, cleaned with $\mathrm{HCl}$ solution $(\mathrm{pH} 2.5)$, and rinsed with ultrapure water to remove any

33 impurities and the outer layers. After each experiment, the cell was soaked in $\mathrm{HCl}$ solution (pH

34 2.5) overnight and rinsed with ultrapure water to remove iron residues (and other acid-soluble

35 contamination). The total iron dosage was controlled by adjusting electrolysis time at a fixed

36 current density of $2.8 \mathrm{~mA} / \mathrm{cm}^{2}$ (see Section S4). For phage infectivity assay, $\mathrm{Na}_{2} \mathrm{SO}_{3}$ was added to

37 the collected samples as a scavenger of $\mathrm{H}_{2} \mathrm{O}_{2}$ to prevent further inactivation and, thus to avoid

38 overestimating infective viruses. ${ }^{4}$ Afterwards, samples were centrifuged to separate flocs at 12,000

$39 \mathrm{~g}$ for $30 \mathrm{~min}$. After centrifugation, infective MS2 remaining in supernatant was enumerated

40 representing the bulk water concentration. Collected iron flocs were re-dissolved in beef extract

41 solution $(\mathrm{pH} 9.5)$ to extract MS2 phages representing the floc concentration. The procedure for

42 phage extraction was validated as explained below in Section S5. The detection limit of infectivity

43 assay in both bulk water and flocs was $100 \mathrm{PFU} / \mathrm{mL}$, which was determined based on the linearity

44 between logarithm of dilution factor and PFU count, ${ }^{5}$ and the volume of phage samples plated $(0.1$

$45 \mathrm{~mL}$ ). As shown in Figure S1, a linear behavior was observed among averages of plaque counts at

46 different dilution factors when plaque counts were more than 10 PFU for both bulk water and floc

47 concentration counting $\left(\mathrm{R}^{2}=0.994\right.$ and 0.996 , respectively). Hence, only plates showing more than

4810 plaques were used for assay which is the same protocol as in earlier literature. ${ }^{6-8}$ The detection

49 limit for both assays (i.e. in flocs and bulk water) was determined as $10 \mathrm{PFU} / 0.1 \mathrm{~mL}=100$

$50 \mathrm{PFU} / \mathrm{mL} .^{6}$ 

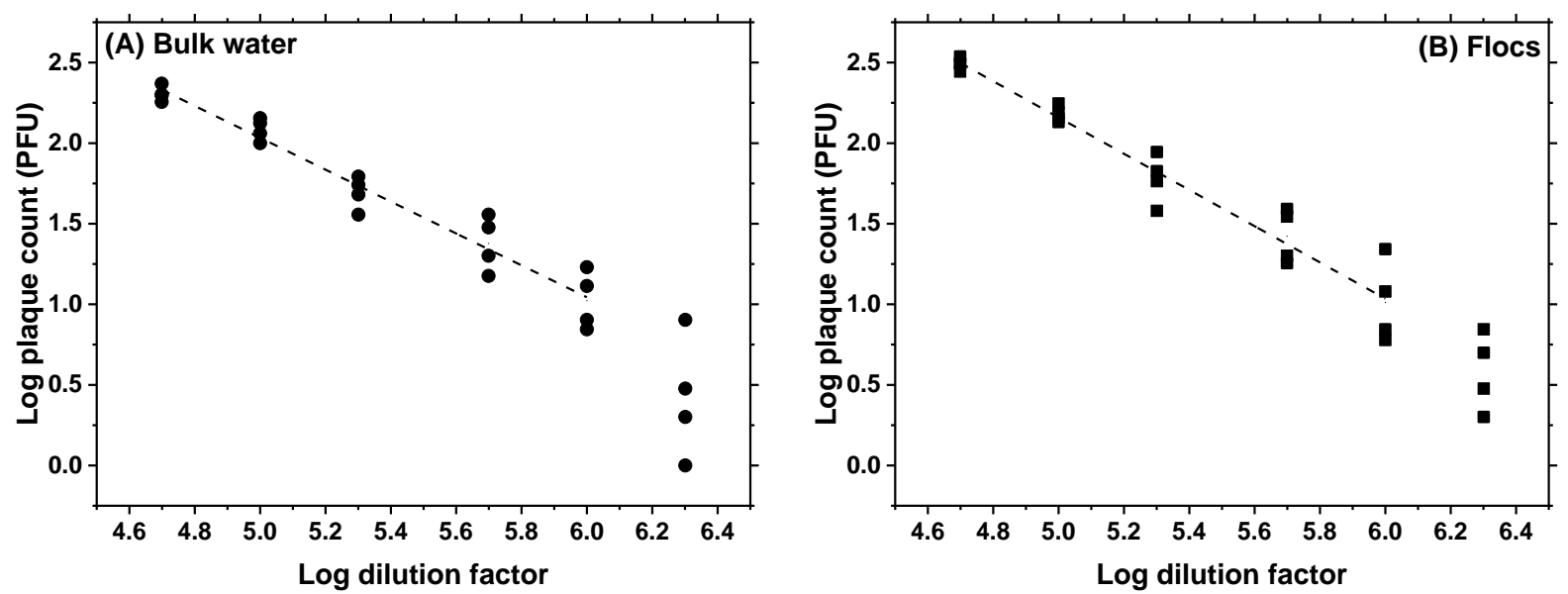

Figure S1. Linear relation between log plaque counts and log dilution factors was only valid when plaque count was more than 10 PFU for both assays. The bulk water data are shown on the left panel and results from the flocs are on the right panel. Individual symbols represent plaque counts from different plates. 
55 Section S3. Comparison of Electrocoagulation Experiments. Table S1 summarizes electrocoagulation system set-ups and

56 experimental conditions for various target contaminants. As seen, the key experimental conditions such as $\mathrm{pH}$, current density and iron

57 dosage in this study (pH 6.4 and $8.2,2.8 \mathrm{~mA} / \mathrm{cm}^{2}$, and $5 \sim 2500 \mathrm{mg} / \mathrm{L} \mathrm{Fe}$, respectively) are within the range of previously employed

58 values ( $\mathrm{pH} 4 \sim 11,0.02 \sim 250 \mathrm{~mA} / \mathrm{cm}^{2}$, and $0.7 \sim 500 \mathrm{mg} / \mathrm{L} \mathrm{Al}$ or Fe).

59 Table S1. Comparison of experimental set-ups and conditions for electrocoagulation of various target contaminant.

\begin{tabular}{|c|c|c|c|c|c|c|c|}
\hline $\begin{array}{c}\text { Target } \\
\text { contaminant }\end{array}$ & Solution composition & pH & $\begin{array}{c}\text { Electrode material } \\
\text { (anode/cathode) }\end{array}$ & $\begin{array}{c}\text { Electrode geometry } \\
\text { (anode/cathode) }\end{array}$ & $\begin{array}{c}\text { Current density } \\
\left(\mathrm{mA} / \mathrm{cm}^{2}\right)\end{array}$ & $\begin{array}{c}\text { Dose } \\
\text { (mg/L Al or Fe) }\end{array}$ & Reference \\
\hline Bacteriophage MS2 & $\begin{array}{c}\text { Synthetic water } \\
\left(\mathrm{NaHCO}_{3}, \mathrm{CaCl}_{2}\right)\end{array}$ & $6.4,8.2$ & $\mathrm{Fe} /$ stainless steel & $\begin{array}{l}\text { Rod/hollow cylinder } \\
0.2 \mathrm{~cm} \text { gap }\end{array}$ & 2.8 & $5,10,20$ & This study \\
\hline Bacteriophage MS2 & $\begin{array}{c}\text { Natural water, } \\
\text { Synthetic water } \\
\left(\mathrm{NaHCO}_{3}, \mathrm{CaCl}_{2}\right)\end{array}$ & $6.4,7.5$ & $\mathrm{Fe} /$ stainless steel & Not specified & $0.8,2.1,2.7$ & $\sim 12$ & 9 \\
\hline Bacteriophage MS2 & Natural water & 6.4 & $\mathrm{Al} /$ stainless steel & Rod/ not specified & 20 & $\sim 30$ & 10 \\
\hline Bacteriophage MS2 & $\begin{array}{l}\text { Synthetic water } \\
\left(\mathrm{NaHCO}_{3}, \mathrm{NaCl}\right)\end{array}$ & $6.2,8.2$ & $\mathrm{Al} /$ stainless steel & Rod/hollow cylinder & 20 & $\sim 30$ & 11 \\
\hline $\begin{array}{c}\text { Bacteriophage MS2 } \\
\text { Bacteriophage } \phi X 174 \\
\text { Human echovirus } 12\end{array}$ & $\begin{array}{c}\text { Synthetic water } \\
\left(\mathrm{NaHCO}_{3}\right) \\
\text { Natural water }\end{array}$ & $6,7,8$ & $\mathrm{Fe} / \mathrm{Fe}$ & Plate/plate & 1.1 & $\sim 30$ & 12 \\
\hline $\begin{array}{c}\text { Bacterial indicators } \\
\text { Bacteriophage } \phi X 174\end{array}$ & $\begin{array}{l}\text { Synthetic effluent water } \\
\text { Secondary effluent }\end{array}$ & 7.3 & $\mathrm{Fe} / \mathrm{Fe}$ & $\begin{array}{l}\text { Plate/plate } \\
1 \mathrm{~cm} \text { gap }\end{array}$ & $1.3 \sim 19$ & $2.9 \sim 116.1$ & 13 \\
\hline $\begin{array}{c}\text { Mammalian viruses } \\
\text { Bacteriophages }\end{array}$ & $\begin{array}{c}\text { Synthetic water } \\
\left(\mathrm{NaNO}_{3}, \mathrm{NaHCO}_{3}\right)\end{array}$ & $6,7,8$ & $\mathrm{Fe} / \mathrm{Fe}$ & $\begin{array}{c}\text { Plate/plate } \\
1 \mathrm{~cm} \text { gap }\end{array}$ & 1.7 & 2.3 & 14 \\
\hline Escherichia coli & Synthetic groundwater & $6.6,7.5$ & $\mathrm{Fe} / \mathrm{Fe}$ & $\begin{array}{l}\text { Plate } / \text { plate } \\
0.5 \mathrm{~cm} \text { gap }\end{array}$ & $0.33 \sim 10$ & $6 \sim 140$ & 15 \\
\hline $\begin{array}{c}\text { Escherichia coli } \\
\text { Enterococcus faecalis }\end{array}$ & Synthetic groundwater & 7 & $\mathrm{Fe} / \mathrm{Fe}$ & $\begin{array}{l}\text { Plate/plate } \\
0.5 \mathrm{~cm} \text { gap }\end{array}$ & 10 & 28 & 16 \\
\hline Boron & Natural water & 7.8 & $\mathrm{Al} / \mathrm{Al}$ & $\begin{array}{c}\text { Rod/rod } \\
2.5 \mathrm{~cm} \text { gap }\end{array}$ & $18 \sim 250$ & $\sim 2500$ & 17 \\
\hline Boron & Synthetic produced water & 7.8 & $\mathrm{Al} / \mathrm{Al}$ & $\begin{array}{l}\text { Plate } / \text { plate } \\
0.5 \mathrm{~cm} \text { gap }\end{array}$ & $6.25 \sim 18.8$ & $36 \sim 320$ & 18 \\
\hline Cr-EDTA & Synthetic wastewater & 7.8 & $\mathrm{Fe} / \mathrm{Fe}$ & Rod/rod & 64 & $\sim 300$ & 19 \\
\hline $\mathrm{Cr}(\mathrm{IV})$ & $\begin{array}{c}\text { Synthetic water } \\
\left(\mathrm{NaNO}_{3}, \mathrm{Na}_{2} \mathrm{HPO}_{4}\right. \\
\left.\mathrm{Na}_{2} \mathrm{SiO}_{3}, \mathrm{Na}_{2} \mathrm{SO}_{4}\right)\end{array}$ & $6,7,8$ & $\mathrm{Fe} / \mathrm{Fe}$ & $\begin{array}{l}\text { Rod/rod } \\
2 \mathrm{~cm} \text { gap }\end{array}$ & 0.99 & $\sim 10$ & 20 \\
\hline
\end{tabular}




\begin{tabular}{|c|c|c|c|c|c|c|c|}
\hline $\mathrm{Cr}(\mathrm{IV})$ & $\begin{array}{c}\text { Synthetic water } \\
\left(\mathrm{NaNO}_{3}, \mathrm{Na}_{2} \mathrm{HPO}_{4},\right. \\
\left.\mathrm{Na}_{2} \mathrm{SiO}_{3}, \mathrm{Na}_{2} \mathrm{SO}_{4}\right)\end{array}$ & $6 \sim 9$ & $\mathrm{Fe} / \mathrm{Fe}$ & $\begin{array}{l}\text { Rod/rod } \\
2 \mathrm{~cm} \text { gap }\end{array}$ & 0.99 & $\sim 10$ & 21 \\
\hline $\mathrm{As}(\mathrm{III})$ & Synthetic groundwater & 7 & $\mathrm{Fe} / \mathrm{Fe}$ & $\begin{array}{l}\text { Plate } / \text { plate } \\
7.5 \mathrm{~cm} \text { gap }\end{array}$ & $0.15 \sim 3.6$ & $\sim 43$ & 22 \\
\hline $\mathrm{As}(\mathrm{III})$ & Synthetic groundwater & 7 & $\begin{array}{c}\mathrm{Fe} / \mathrm{Fe} \\
\text { Fe/carbon }\end{array}$ & $\begin{array}{c}\text { Plate/plate or cloth } \\
0.7,2.5 \mathrm{~cm} \text { gap }\end{array}$ & $0.14 \sim 56$ & 174 & 23 \\
\hline $\mathrm{As}(\mathrm{III})$ & Synthetic groundwater & 7 & $\mathrm{Fe} / \mathrm{Cu}$ & $\begin{array}{c}\text { Wire } / \text { mesh } \\
1 \mathrm{~cm} \text { gap } \\
\end{array}$ & $0.02 \sim 100$ & 22,51 & 24 \\
\hline As & Natural groundwater & 7.1 & $\mathrm{Fe} / \mathrm{Fe}$ & $\begin{array}{l}\text { Plate } / \text { plate } \\
5 \mathrm{~cm} \text { gap }\end{array}$ & 0.3 & 130 & 25 \\
\hline $\mathrm{As}(\mathrm{III}) /(\mathrm{V})$ & $\begin{array}{c}\text { Synthetic water } \\
(\mathrm{NaCl})\end{array}$ & $7 \sim 8$ & $\mathrm{Fe} / \mathrm{Fe}$ & $\begin{array}{c}\text { Plate/plate } \\
1 \mathrm{~cm} \text { gap }\end{array}$ & $3.5 \sim 40$ & $3.5 \sim 70$ & 26 \\
\hline $\mathrm{As}(\mathrm{III}) /(\mathrm{V})$ & $\begin{array}{c}\text { Synthetic water } \\
\left(\mathrm{Na}_{2} \mathrm{HPO}_{4}, \mathrm{Na}_{2} \mathrm{SiO}_{3}\right. \\
\left.\mathrm{Na}_{2} \mathrm{SO}_{4}, \mathrm{NaHCO}_{3}\right)\end{array}$ & $5 \sim 9$ & $\mathrm{Fe} / \mathrm{Fe}$ & $\begin{array}{l}\text { Rod/rod } \\
2 \mathrm{~cm} \text { gap }\end{array}$ & 0.39 & 50 & 27 \\
\hline $\mathrm{U}(\mathrm{VI})$ & $\begin{array}{c}\text { Synthetic water } \\
\left(\mathrm{Na}_{2} \mathrm{SO}_{4}\right)\end{array}$ & $3.0 \sim 9.0$ & Fe/graphite & $\begin{array}{c}\text { Plate } / \text { plate } \\
5 \mathrm{~cm} \text { gap }\end{array}$ & $0.6 \sim 1.4$ & $\sim 100$ & 28 \\
\hline Natural organic matter & $\begin{array}{l}\text { Synthetic water } \\
\left(\mathrm{Na}_{2} \mathrm{SO}_{4}\right)\end{array}$ & 7 & $\mathrm{Fe} /$ stainless steel & $\begin{array}{l}\text { Plate } / \text { plate } \\
0.2 \mathrm{~cm} \text { gap }\end{array}$ & $2.5 \sim 27$ & 300 & 29 \\
\hline Natural organic matter & $\begin{array}{c}\text { Natural water } \\
\text { Synthetic water } \\
(\mathrm{NaCl})\end{array}$ & $6.6,7.9$ & $\mathrm{Fe} /$ stainless steel & $\begin{array}{c}\text { Plate } / \text { plate } \\
0.1,0.2,1 \mathrm{~cm} \text { gap }\end{array}$ & $3.6 \sim 28$ & $25.7 \sim 51.1$ & 30 \\
\hline Natural organic matter & Natural water & $6 \sim 9$ & $\mathrm{Fe} / \mathrm{Pt}$ & $\begin{array}{l}\text { Foil/foil } \\
1 \mathrm{~cm} \text { gap }\end{array}$ & $1 \sim 25$ & $6 \sim 12$ & 31 \\
\hline Soluble phosphorous & Natural water & $7.8 \sim 8.3$ & $\mathrm{Fe} / \mathrm{Fe}$ or $\mathrm{Al} / \mathrm{Al}$ & $\begin{array}{l}\text { Plate } / \text { plate } \\
2.5 \mathrm{~cm} \text { gap }\end{array}$ & $\begin{array}{l}1 \sim 10(\mathrm{Fe}) \\
2 \sim 15(\mathrm{Al})\end{array}$ & $\begin{aligned} 2.6 \sim 16(\mathrm{Fe}) \\
0.7 \sim 4.3(\mathrm{Al})\end{aligned}$ & 32 \\
\hline Phosphate & Wastewater & $6.8 \sim 7.1$ & $\begin{array}{c}\mathrm{Fe} \text { or } \mathrm{Al} / \text { activated } \\
\text { carbon }\end{array}$ & Mesh/air cathode & 1 & - & 33 \\
\hline Phosphite & $\begin{array}{l}\text { Synthetic water } \\
\left(\mathrm{Na}_{2} \mathrm{SO}_{4}\right)\end{array}$ & 4 & $\mathrm{Fe} /$ stainless steel & $\begin{array}{l}\text { Plate/plate } \\
1 \mathrm{~cm} \text { gap }\end{array}$ & $12.5 \sim 50$ & 500 & 34 \\
\hline Erochrome Black T & $\begin{array}{c}\text { Synthetic water } \\
\left(\mathrm{NaCl} \text { or } \mathrm{Na}_{2} \mathrm{SO}_{4}\right)\end{array}$ & $4 \sim 11$ & $\mathrm{Al} / \mathrm{Al}$ & $\begin{array}{l}\text { Plate } / \text { plate } \\
0.9 \mathrm{~cm} \text { gap }\end{array}$ & 1.4 & $12 \sim 14$ & 35 \\
\hline Bronopol & Synthetic wastewater & 6.5 & $\mathrm{Fe}, \mathrm{Al} /$ stainless steel & $\begin{array}{c}\text { Plate } / \text { plate } \\
1 \sim 4 \mathrm{~cm} \text { gap }\end{array}$ & $11 \sim 66$ & - & 36 \\
\hline Perfluoroalkyl acids & $\begin{array}{c}\text { Synthetic water } \\
(\mathrm{NaCl})\end{array}$ & 5 & $\begin{array}{l}\mathrm{Fe}, \mathrm{Al}, \mathrm{Mg}, \mathrm{Zn} \\
\text { /stainless steel }\end{array}$ & $\begin{array}{c}\text { Plate/plate or } \\
\text { Sheet/rod }\end{array}$ & 0.5 & $\sim 150$ & 37 \\
\hline Total trihalomethane & $\begin{array}{c}\text { Synthetic water } \\
\left(\mathrm{NaHCO}_{3}, \mathrm{KCl}, \mathrm{NaBr}\right)\end{array}$ & $6 \sim 9$ & $\mathrm{Fe} / \mathrm{Fe}$ & Not specified & 5.55 & 6.4 & 38 \\
\hline
\end{tabular}


61 Section S4. Dosage Control Using Faraday's Law. Electrolysis was performed for

62 predetermined time durations calculated using Faraday's law (both sides were divided by volume

63 to obtain concentration, Equation S1) to add targeted total iron dosages (78 s, $156 \mathrm{~s}$, and $312 \mathrm{~s}$ for

$645 \mathrm{mg} / \mathrm{L}, 10 \mathrm{mg} / \mathrm{L}$, and $20 \mathrm{mg} / \mathrm{L}$, respectively), and total iron concentration was measured in the

65 middle and at the end of electrolysis. Figure S2 compares purely theoretical predictions of total

66 iron concentration with experimentally measured concentrations when the number of electrons

67 transferred $(\mathrm{z})$ is assumed to be 2 . As seen, experimentally measured total iron concentrations

68 agreed extremely well with theoretical Faraday’s law prediction with no fitting parameters for $\mathrm{z}=$

692 at both $\mathrm{pH}$ values providing strong evidence that $\mathrm{Fe}(\mathrm{II})$ is generated during electrolysis as shown

70 earlier. $^{21,31,39}$

$71 \quad \frac{m}{V}=\frac{A_{w} \cdot I \cdot t}{z \cdot F \cdot V}$

72 where, $\mathrm{m}$ is mass of total iron $(\mathrm{g}), \mathrm{V}$ is the electrolytic cell volume $(0.45 \mathrm{~L}), \mathrm{A}_{\mathrm{w}}$ is an atomic mass

73 of iron $(55.85 \mathrm{~g} / \mathrm{mol})$, $\mathrm{I}$ is electrical current $(0.1 \mathrm{~A}), \mathrm{t}$ is electrolysis time $(\mathrm{s}), \mathrm{z}$ is the number of

74 electrons transferred (=2 here), and F is Faraday's constant $(96,486 \mathrm{C} / \mathrm{eq})$.

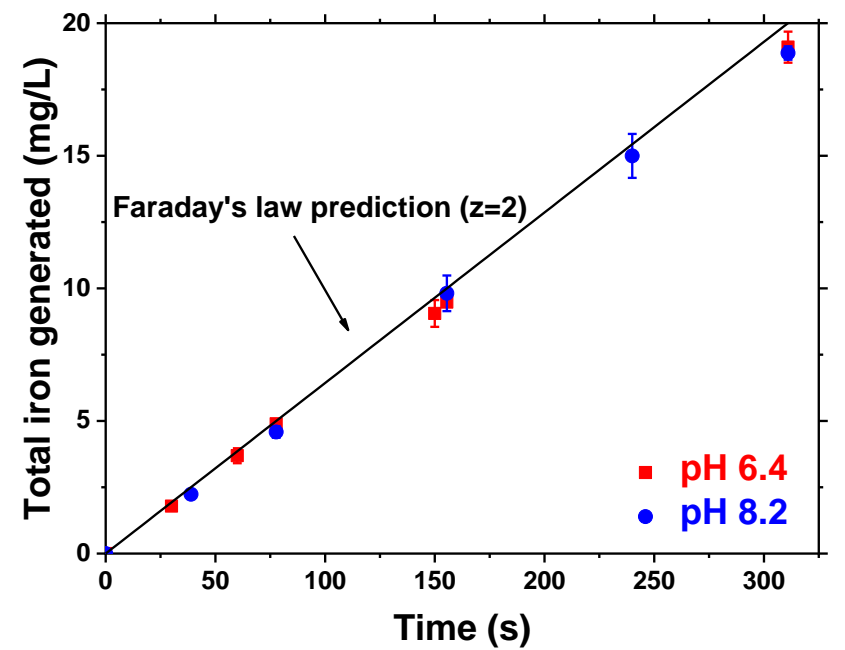

Figure S2. Strong evidence of Fe(II) production during electrocoagulation via excellent agreement between Faraday's law and experimental measurements of total iron in all cases. A 2-electron transfer quantitatively explains our experimental observations without any fitting demonstrating anodic oxidation produces Fe(II). 
Section S5. Recovery of MS2 from Iron Flocs. The procedure for MS2 phage recovery from iron flocs using $6 \%$ beef extract solution ( $\mathrm{pH} 9.5$ ) was validated. Conventional chemical coagulation with $\mathrm{Fe}(\mathrm{III})$ at $\mathrm{pH} 6.4$ and 8.2 was performed to avoid inactivation of MS2 phages, which makes

82 it a suitable condition to verify that all MS2 phages sorbed in flocs are recoverable if not 83 inactivated following the protocol. MS2 phages were spiked in the cell to achieve an initial 84 concentration of $\mathrm{O}\left(10^{8}\right) \mathrm{PFU} / \mathrm{mL}$. Afterwards, $\mathrm{Fe}(\mathrm{III})$ coagulant was added at three target dosages 85 (5 mg/L, $10 \mathrm{mg} / \mathrm{L}$, and $20 \mathrm{mg} / \mathrm{L})$. The solution was rapidly mixed for $2 \mathrm{~min}$ followed by a slow mixing for a total time of $120 \mathrm{~min}$. Sorbed MS2 phage concentration was calculated by subtracting bulk water concentration at $\mathrm{t}=120 \mathrm{~min}$ from initial concentration and compared to that of MS2 phages recovered from flocs (Figure S3). Statistical comparison ( $t$ test, $\mathrm{n}=3 \sim 5, p<0.05$ for statistically significant difference) of sorbed and recovered MS2 phages resulted in insignificant differences between two concentrations indicating that phages were fully recovered from iron flocs

91 at all dosages and $\mathrm{pH}$ conditions. Hence, the recovery procedure is valid and, thus, any reduction in virus floc concentration during electrocoagulation is solely due to inactivation. In addition,

93 phage recovery during the course of experiment is shown in Figure S4. At all time points, 94 insignificant difference between sorbed and recovered MS2 concentration was obtained $(t$ test, $\mathrm{n}=$ $954, p<0.05$ for statistically significant difference).

These results correspond with earlier reports from our group using aluminum 97 electrocoagulation and conventional coagulation. ${ }^{10,40,41}$ Further, this is the basis of the "Standard 98 Method" for concentrating viruses from water and wastewater samples. ${ }^{2}$ In other words, our results 99 fully agree with conventional chemical coagulation with alum and iron salts solely removing 100 microorganisms without inactivating them. 

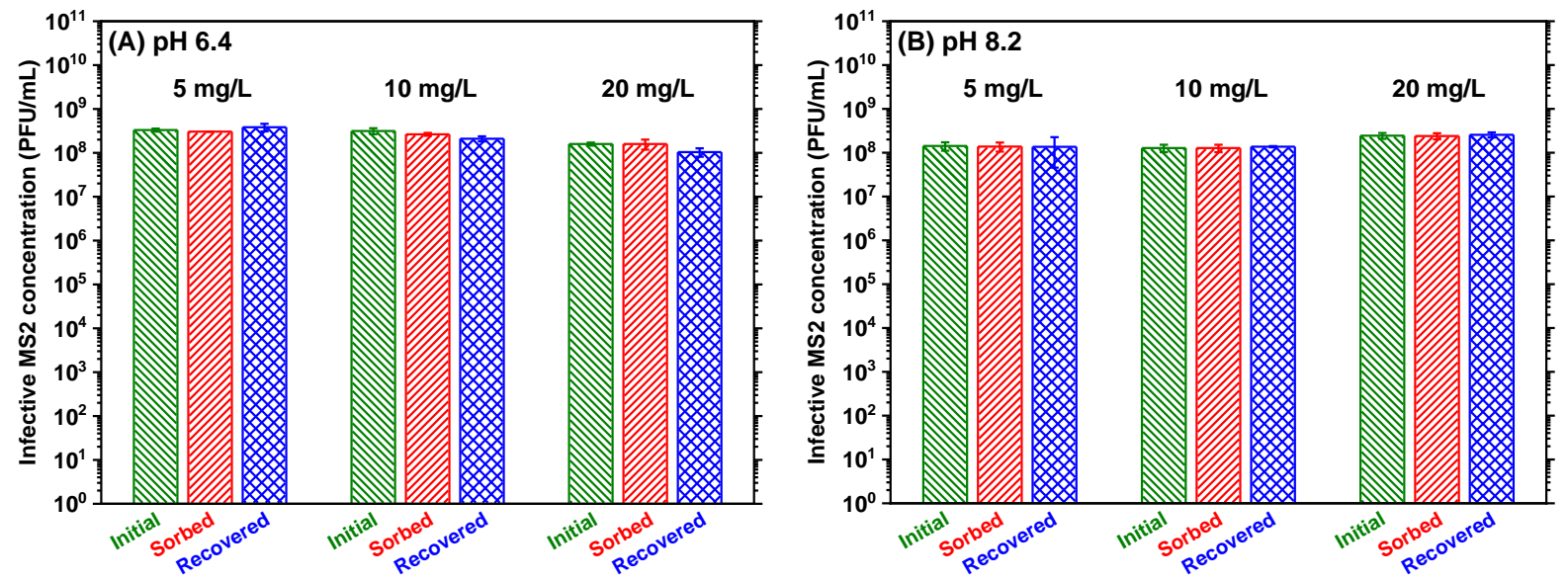

101

102

103

104

105

106

107

108
Figure S3. Complete recovery of MS2 phages using $6 \%$ beef extract solution from iron flocs generated with $\mathrm{FeCl}_{3}$ at all dosages used in this study at $\mathrm{pH} 6.4$ (A) and 8.2 (B). It is noted that the phages were extracted at the end of flocculation ( $\mathrm{t}=120 \mathrm{~min}) . t$ test between sorbed and recovered phage concentrations indicated insignificant differences at all conditions.

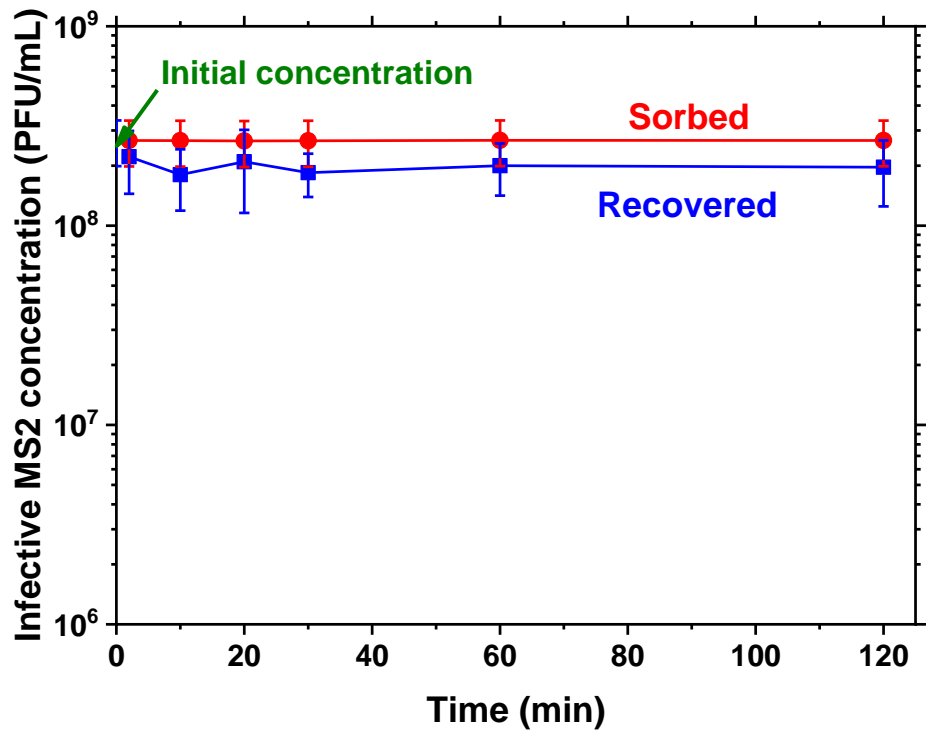

Figure S4. Time series of MS2 recovery from the flocs at $\mathrm{pH} 6.4$ when $10 \mathrm{mg} / \mathrm{L} \mathrm{Fe}$ was added as $\mathrm{FeCl}_{3}$. $t$ test between sorbed and recovered phage concentrations indicated insignificant differences at all time points. 
109 Section S6. Analytical Methods. Total iron and Fe(II) concentration were measured with a 110 spectrophotometer (DR6000, HACH). Total iron was measured following HACH method 8112 in 111 which $\mathrm{Fe}(\mathrm{III})$ is reduced by sodium metabisulfite to $\mathrm{Fe}(\mathrm{II})$, and $\mathrm{Fe}(\mathrm{II})$ forms a complex with 2,4,6112 Tris(2-pyridyl)-s-triazine. Violet-colored complex was quantified by light absorption at $590 \mathrm{~nm}$. 113 Ferrous iron concentration was determined using $\mathrm{HACH}$ method 8146 where 1,10-phenanthroline 114 is used as a chelating agent for $\mathrm{Fe}(\mathrm{II})$ after adding $\mathrm{HCl}$ to adjust $\mathrm{pH}$ to 3. The complex of $\mathrm{Fe}$ (II) 115 and 1,10-phenanthrolie was quantified by light absorption at $510 \mathrm{~nm} .^{39,42,43}$

$116 \mathrm{H}_{2} \mathrm{O}_{2}$ was measured based on the reduction of $\mathrm{Cu}(\mathrm{II})$ to $\mathrm{Cu}$ (I) by $\mathrm{H}_{2} \mathrm{O}_{2}$ and the formation of $117 \mathrm{Cu}(\mathrm{I})-2,9-$ dimethyl-1,10-phenanthroline complex. ${ }^{44,45}$ Samples were filtered with $0.1 \mu \mathrm{m}$ syringe 118 filter followed by citrate $(7.2 \mathrm{mM})$ addition in order to prevent the reduction of $\mathrm{Cu}$ (II) by $\mathrm{Fe}$ (II). ${ }^{46}$ 119 Orange-colored complex was quantified by light absorption at $454 \mathrm{~nm}$ (DR-6000, HACH). 
120 Section S7. ATR-FTIR. ATR-FTIR spectra were collected using Nicolet iS10 spectrometer

121 (Thermo Fisher Scientific) equipped with an Ever-Glo MIR source, DTGS detector, KBr beam

122 splitter and Omnic 9 software. Samples were directly mounted on a diamond iTX accessory and

123 spectra were obtained in ATR mode. Each spectrum reported herein is an average of three to five

124 measurements consisting of 128 coadded scans at $4 \mathrm{~cm}^{-1}$ resolution. ATR-correction was

125 conducted followed by auto-base line correction and 9-point Savitzky-Golay smoothing. The

126 spectra were normalized by the largest peak intensity. ${ }^{47}$ Peak positions were identified by taking

127 the second derivatives of the spectra.

128 A control was performed to prove these ATR-FTIR signals were not due to residuals (e.g. 129 bacterial debris or other chemicals) or contamination in the virus stock. In addition to "regular" 130 MS2 stock prepared as described in Section S1, a "control" stock was prepared by following the 131 same procedure except for the virus inoculation to bacterial cells. This control stock was expected 132 to only contain residues that might be also in the regular stock.

Untreated MS2 spectrum was obtained by subtracting the spectrum of a freeze-dried control 134 stock from that of freeze-dried regular stock. This subtraction procedure is expected to minimize 135 the interference of potential chemical and biological residues carried over to MS2 stock during its 136 preparation. ${ }^{11,48,49}$ Similarly, for the spectrum of coagulated MS2, coagulation was separately 137 performed with regular and control stock followed by spectrum subtraction to ensure that any 138 changes in spectrum were due to MS2 transformation, not modifications of other residues if there 139 were any. The entire suspension was vacuum-filtered with a glass fiber membrane (1.2 $\mu$ m nominal 140 pore size) followed by vacuum-drying for $6 \sim 9$ hours. The spectrum of each sample was obtained 141 from 3 different locations on the membrane and averaged, and then difference spectrum was 142 obtained. 
143 Section S8. RT-qPCR Protocol. The sample volume of $400 \mu \mathrm{L}$ was added to an equal volume of 144 UNEX lysis buffer ${ }^{50}$ (Microbiologics, St. Cloud, MN), mixed vigorously and incubated at room 145 temperature for $15 \mathrm{~min}$. After incubation, the entire volume of the mixture was added to a silica 146 spin column (Omega Biotek, Norcross, GA) and centrifuged at 10,000 $\mathrm{g}$ for $1 \mathrm{~min}$. After discarding 147 the flow through, the column was washed with $500 \mu \mathrm{L}$ of $100 \%$ ethanol and centrifuged at 10,000 $148 \mathrm{~g}$ for $1 \mathrm{~min}$. The column was washed again with $70 \%$ ethanol at 10,000 $\mathrm{g}$ for $1 \mathrm{~min}$ followed by 149 an extra centrifugation to remove excess ethanol. The RNA was eluted in a clean microcentrifuge 150 tube with $70 \mu \mathrm{L}$ of $10 \mathrm{mM}$ Tris- $1 \mathrm{mM}$ EDTA ( $\mathrm{pH} 8.0$ ) by centrifugation at 10,000 $\mathrm{g}$ for $1 \mathrm{~min}$.

151 Viral RNA was quantified by one-step real-time RT-qPCR ${ }^{11,51}$ with a forward primer $632 \mathrm{~F}$, 152 GTCGCGGTAATTGGCGC, a reverse primer 708R, GGCCACGTGTTTTGATCGA, and a 153 fluorescent probe 650P, 5'-AGGCGCTCCGCTACCTTGCCCT-3' labeled on 5' end with FAM 154 (6-carboxy-fluorecein) and 3' end labeled with black hole quencher in duplicate. RNA was reverse 155 transcribed into complementary DNA (cDNA) and thermocycling comprised 45 cycles of 156 amplification consisting of denaturation at $95^{\circ} \mathrm{C}$ for $5 \mathrm{~s}$, annealing at $60{ }^{\circ} \mathrm{C}$ for $30 \mathrm{~s}$, and acquiring 157 the fluorescence signal, which was used to obtain the cycling threshold (values > 40 were 158 considered negative). Each TaqMan mixture for the reaction consisted of $5 \mu \mathrm{L}$ of $4 \mathrm{X}$ TaqMan Fast 159 Virus 1-Step Mastermix (Life Technologies), $0.8 \mu \mathrm{L}$ of $250 \mathrm{nM}$ each primer, $1 \mu \mathrm{L}$ of $100 \mathrm{nM}$ 160 probe, $10.4 \mu \mathrm{L}$ of nuclease free water and $2 \mu \mathrm{L}$ of RNA sample to a final reaction volume of 20 $161 \mu \mathrm{L}$. All reactions were performed in duplicate on ABI 7500 (Applied Biosystems) with slight 162 modifications to a previously reported protocol. ${ }^{51}$

Duplicates of $2 \mu \mathrm{L}$ sample extract were run along with a positive control and no-template 164 negative control to verify the protocol and check for contamination. Duplicates of the samples 165 were assayed, and the detection limit was determined by the lowest concentration samples 
166 resulting in a positive signal. A standard curve was constructed with 10-fold dilution series of MS2

167 stock of known concentrations. qPCR efficiency was calculated as $91.6 \%$ from the slope of a 168 linear regression curve with 0.99 of $\mathrm{R}^{2}$ (Figure S5).

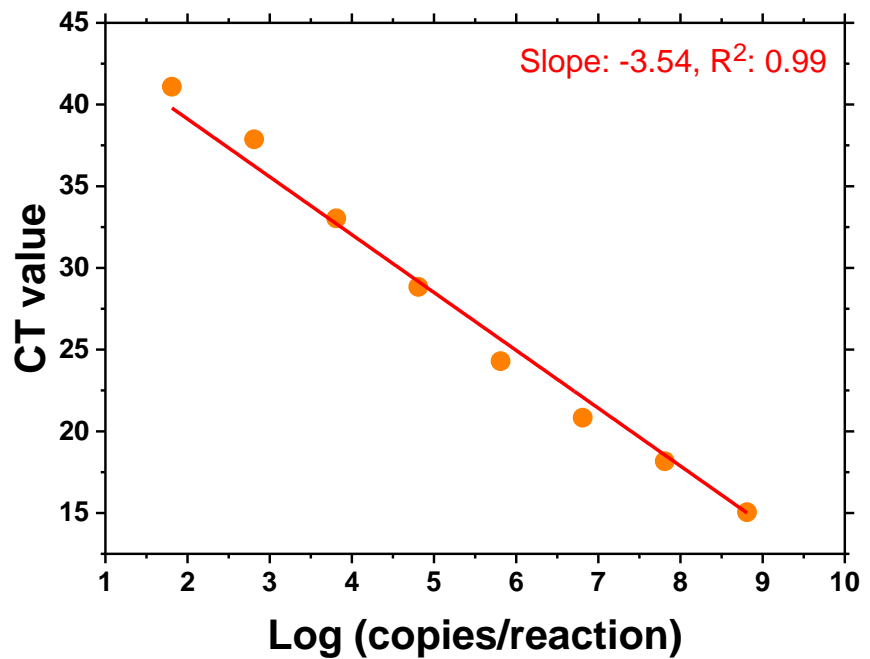

Figure S5. Standard curve of MS2 RNA RT-qPCR. 
171 Section S9. Indirect Evidence of Virus Inactivation. A set of controls was performed to probe

172 the possibility of electrocoagulation inactivating at $\mathrm{pH} 6.4$ by comparing with conventional $\mathrm{FeCl}_{3}$

173 coagulation. Total reductions of MS2 in bulk water by electrocoagulation and $\mathrm{FeCl}_{3}$ chemical

174 coagulation at different $\mathrm{pH}$ and doses are summarized in Figures S6A and S6B. Also, relative

175 reductions were calculated by dividing $\mathrm{EC}$ reductions by $\mathrm{FeCl}_{3}$ reductions and plotted in Figure

176 S6C. Note that MS2 is not inactivated by conventional $\mathrm{FeCl}_{3}$ coagulation at $\mathrm{pH} 6.4$ (SI Section

177 S5). ${ }^{14,40,41}$ Importantly, as shown in SI Section S5 and Figure S6, infective MS2 was reduced in

178 bulk water to a substantially greater extent ( $8 \sim 500$ times) by $\mathrm{EC}$ than $\mathrm{FeCl}_{3}$ (red line in Figure

179 S6C) demonstrating bulk inactivation at $\mathrm{pH}$ 6.4. In flocs, unlike $\mathrm{FeCl}_{3}$ coagulation where infective

180 viruses were completely recovered from flocs (i.e. only removal), MS2 was only partially extracted

181 from EC flocs by the plaque assay indicating loss of infectivity showing monotonic decrease over

182 time (Figure 1B in the main manuscript text) suggesting progressive inactivation. Hence, EC at

$183 \mathrm{pH} 6.4$ removed and inactivated viruses. However, at $\mathrm{pH} 8.2$, total virus reduction in bulk water

184 by $\mathrm{EC}$ and $\mathrm{FeCl}_{3}$ coagulation were similar as evidenced by overlapping total reduction curves and

185 relative reduction values close to 1 (Figure S6B and blue line in Figure 1C of the main manuscript)

186 validating negligible inactivation during $\mathrm{EC}$ as well as $\mathrm{FeCl}_{3}$ coagulation at the higher $\mathrm{pH}$.

187

188

189

190

191

192
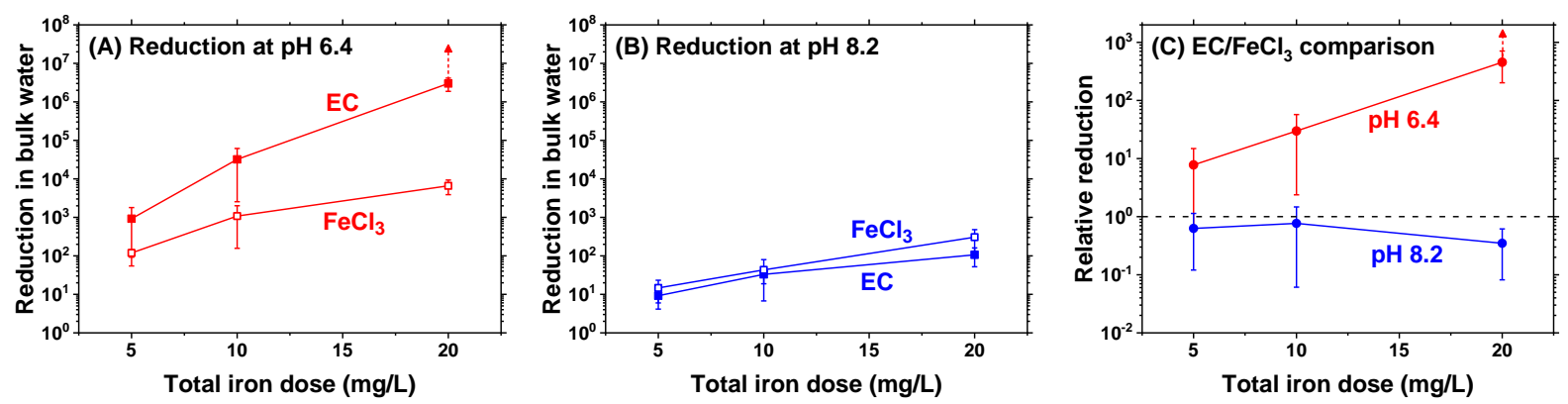

Figure S6. Comparison of log-reduction in bulk water at the end of flocculation ( $\mathrm{t}=120 \mathrm{~min})$ in EC and $\mathrm{FeCl}_{3}$ coagulation at $\mathrm{pH} 6.4(\mathrm{~A})$, at $\mathrm{pH} 8.2(\mathrm{~B})$, and the relative reduction between $\mathrm{EC}$ and $\mathrm{FeCl}_{3}$ calculated by dividing $\mathrm{EC}$ reductions by $\mathrm{FeCl}_{3}$ reductions (C). The $t$ test performed between $\mathrm{EC}$ and $\mathrm{FeCl}_{3}(\mathrm{n}=3 \sim 6$, $p<0.05$ for statistically significant difference) at each dose revealed that mean reductions were statistically different at all doses at pH 6.4 whereas $\mathrm{EC}$ and $\mathrm{FeCl}_{3}$ did not show significant differences at $\mathrm{pH}$ 8.2. 
193 Section S10. Visualization of MS2 Sorbed onto Iron Flocs. MS2 phages were conjugated with

194 fluorescein isothiocyanate isomer 1 (FITC) as described previously. ${ }^{52}$ Briefly, $1 \mathrm{~mL}$ of phage stock

195 prepared in $0.1 \mathrm{M}$ borate buffer ( $\mathrm{pH} 9.2$ ) was mixed with $5 \mathrm{~mL}$ of dimethylformamide and $21 \mathrm{mg}$

196 of FITC. The solution was stored at $4^{\circ} \mathrm{C}$ overnight and dialyzed with $12-14 \mathrm{kDa}$ membrane tube

197 against PBS for 5 days. The end product was further purified by rinsing MS2 phages several time

198 with PBS using a $100 \mathrm{kDa}$ centrifugal filter unit (Spin-X UF, Corning). Upon electrocoagulation

199 of FITC-labeled phages, images were taken with Olympus BX 53. In addition, control experiments

200 were performed to ensure that only FITC-tagged phages were responsible for the fluorescence

201 signal. ${ }^{10}$ Free FITC solution was prepared by following the procedure described above without 202 adding MS2. 
Brightfield transmission mode

(A) Floc with labelled MS2

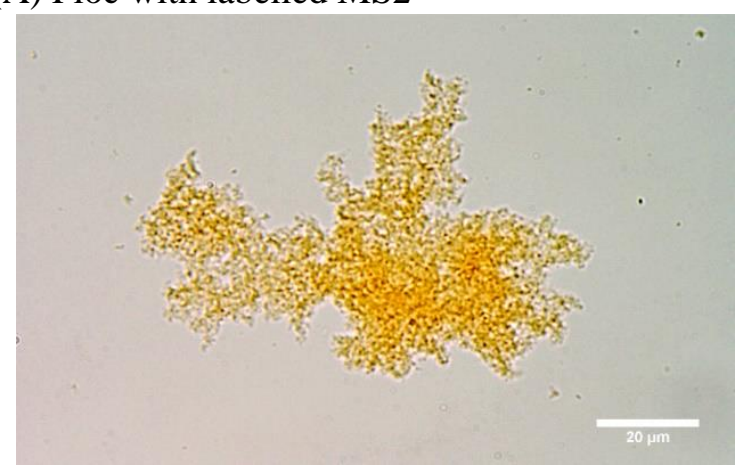

(B) Floc (control)

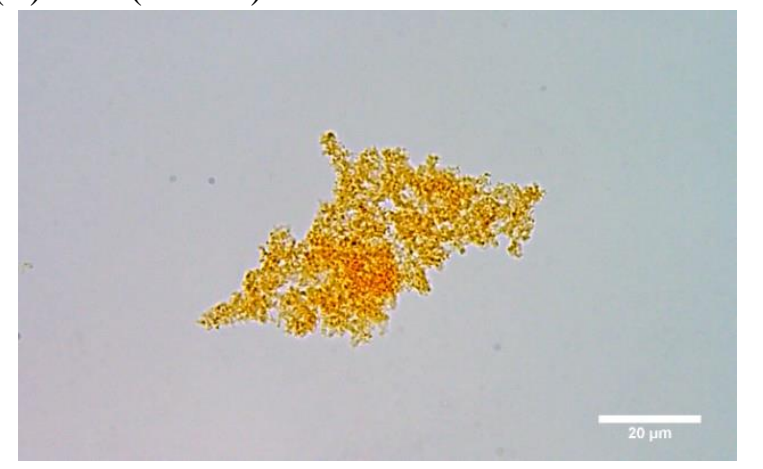

(C) Floc with unlabeled MS2 (control)

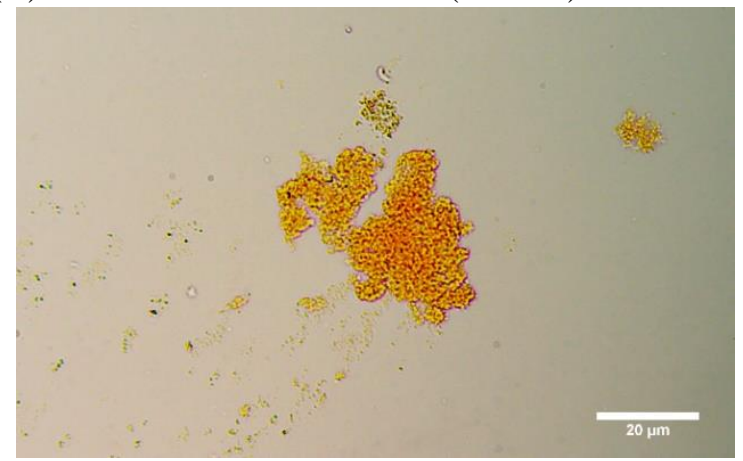

(D) Floc with free FITC (control)

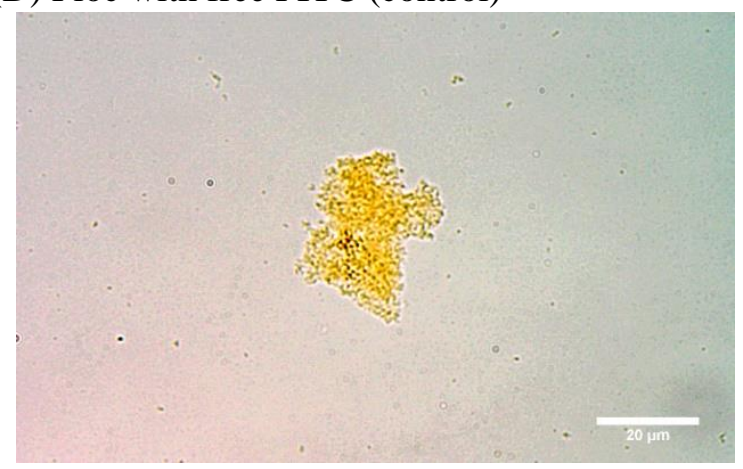

Fluorescence mode
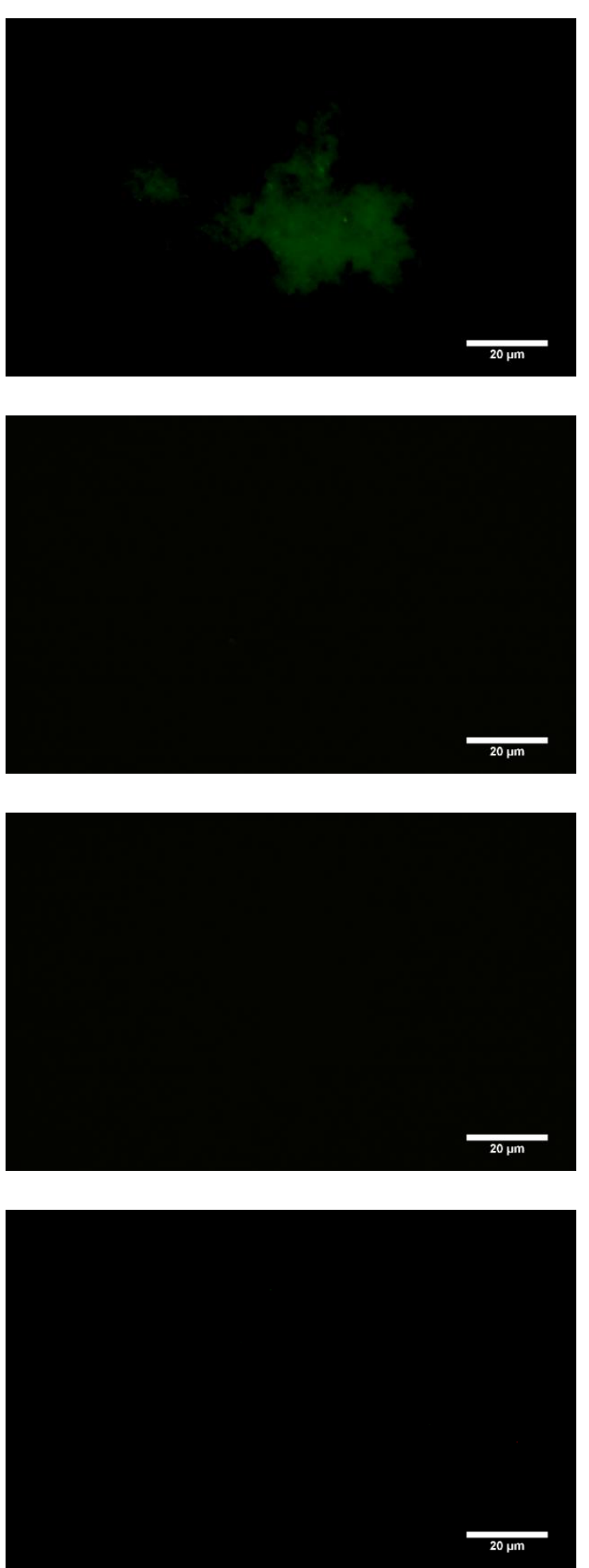

Figure S7. Visualization of phages captured by iron flocs at $10 \mathrm{mg} / \mathrm{L}$ total iron and $\mathrm{pH} 6.4$ (A) along with various controls (B), (C), and (D). Bright field images and corresponding fluorescence images (excitation at $480 \mathrm{~nm}$ and emission at $510 \mathrm{~nm}$, exposure time $200 \mathrm{~ms}$ ) are shown next each other. 
Bright-field transmission mode

(A) Floc with labelled MS2

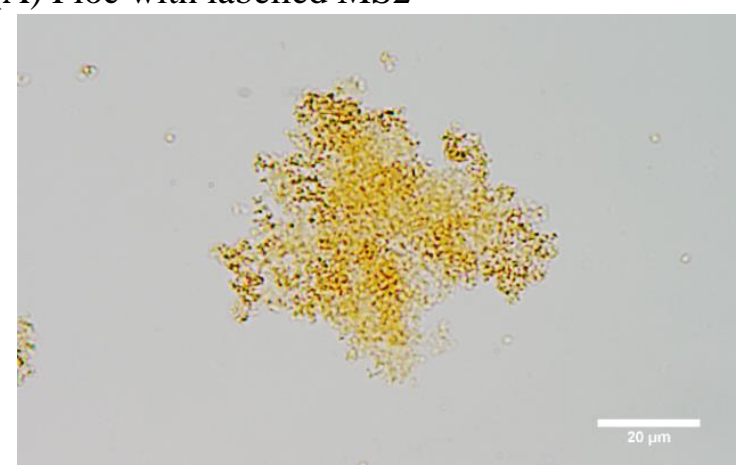

(B) Floc (control)

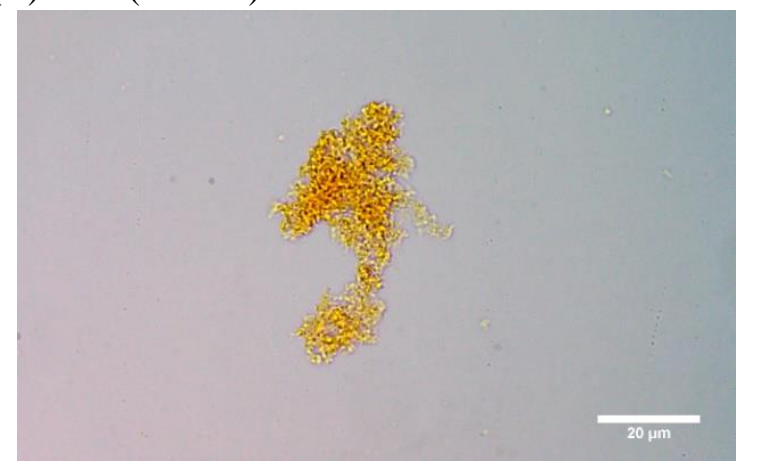

(C) Floc with unlabeled MS2 (control)

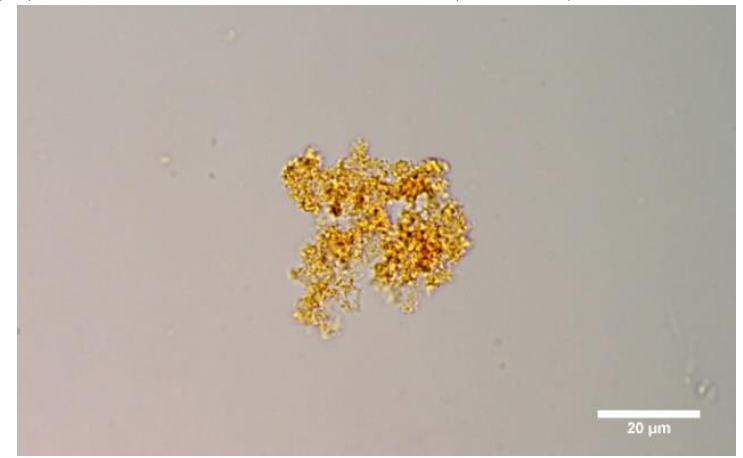

(D) Floc with free FITC (control)

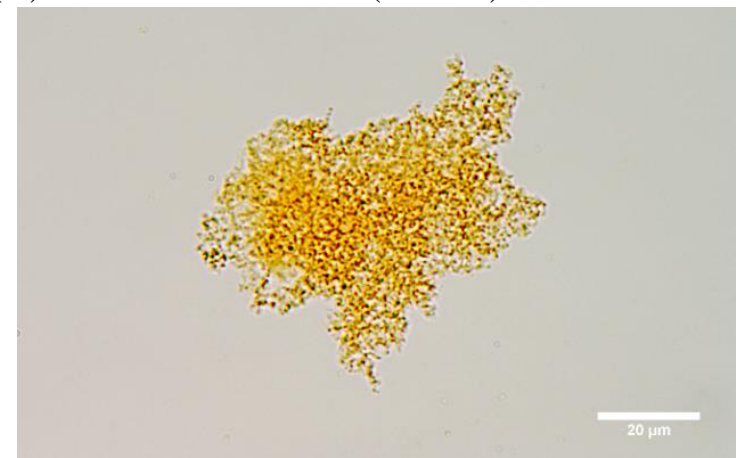

\section{Fluorescence mode}
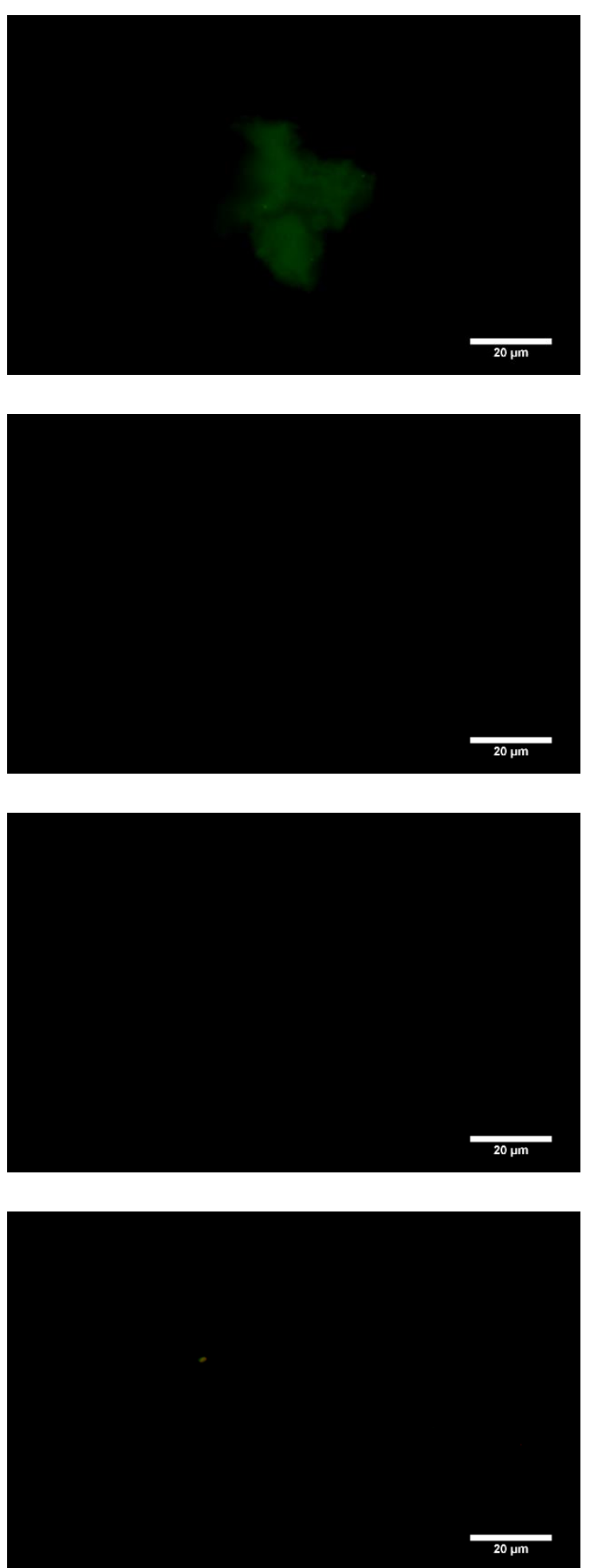

Figure S8. Duplication of Figure S7 at $10 \mathrm{mg} / \mathrm{L}$ total iron and $\mathrm{pH}$ 8.2. Microscopic analysis details are 207 same as the previous figure. 


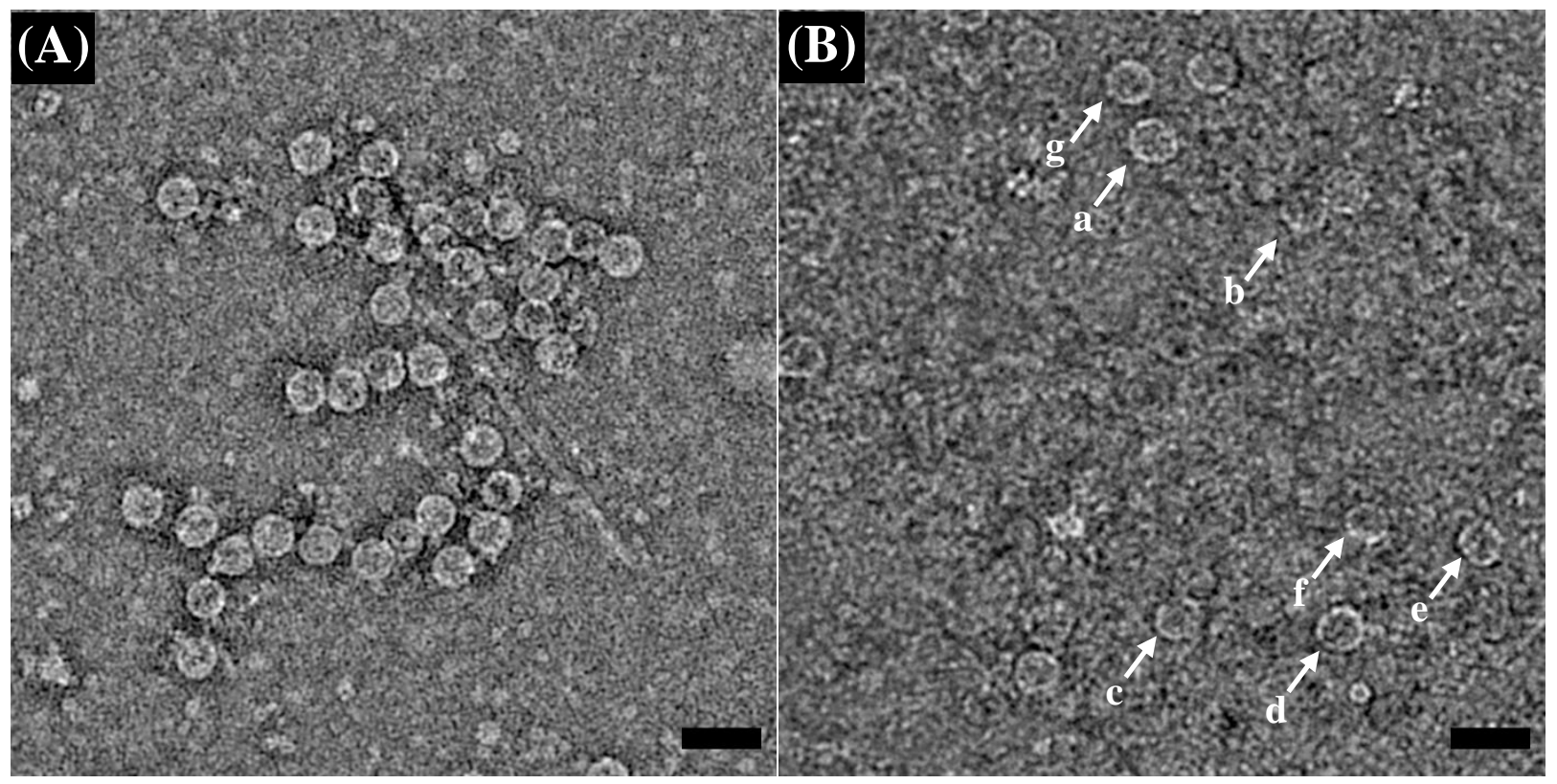

Figure S9. Representative TEMs of untreated (A) and electrocoagulated MS2 (B). Scale bars equal $50 \mathrm{~nm}$.

211 The white arrows with labels in Figure S9B depict the particles that were chosen to be represented in the

212 main manuscript. Particle ' $b$ ' is represented in Figure 3B, and particles 'a-g' were used for the boxed-out

213 images in Figures 4A-4G matching the alphabetical sequence. 


\section{Section S12. Discussion on Viral Capsid Damage.}

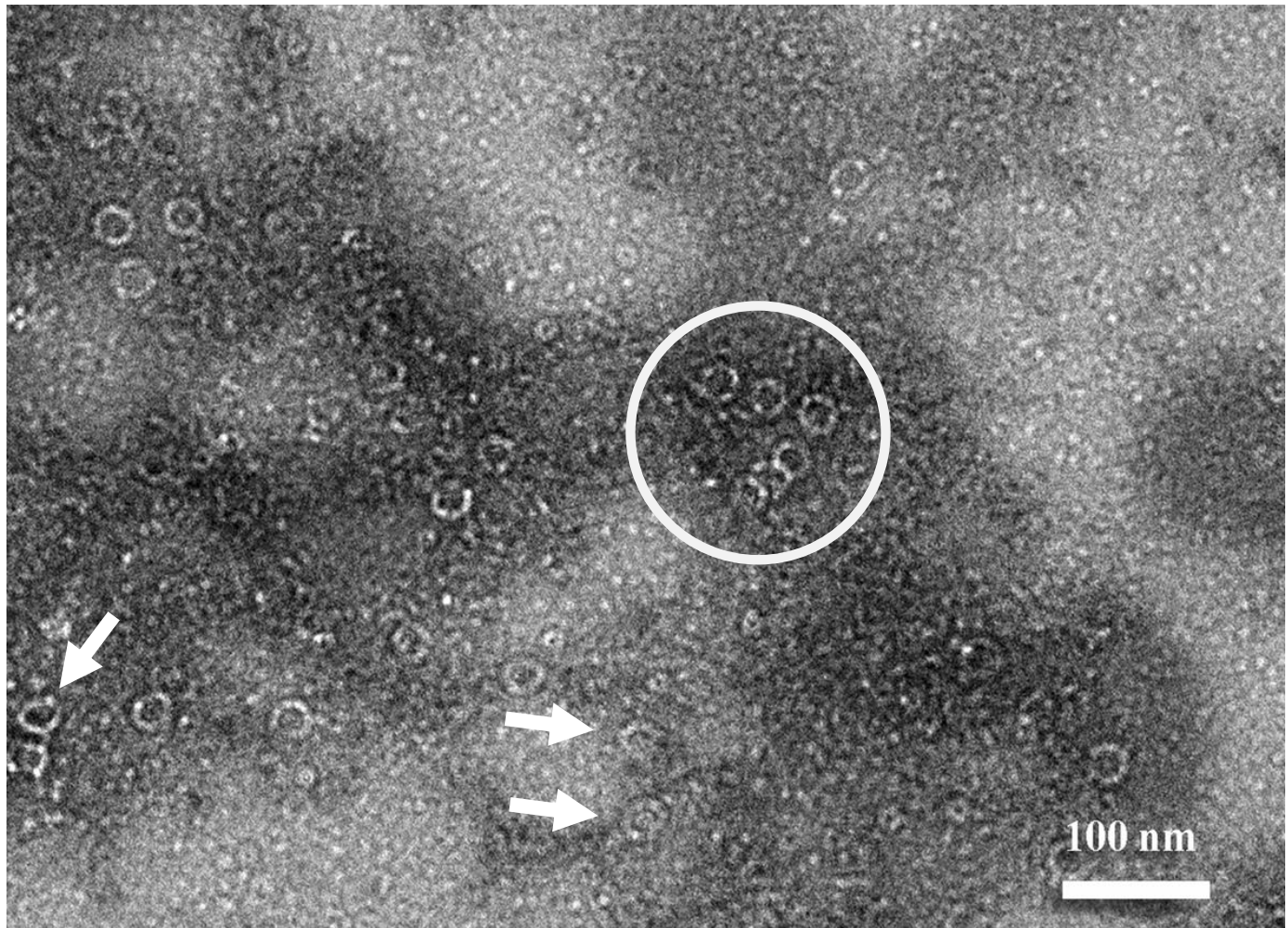

Figure S10. Electron micrograph of electrocoagulated MS2 phages. MS2 particles with deformed/damaged 217 capsids can be seen inside the white circle. A few severely damaged MS2 particles are pointed by white 218 arrows. 
219 Section S13. Visualizing MS2 Embedded in Iron Flocs with Defocusing. Unlike untreated MS2

220 phages imaged on a clean carbon grid, electrocoagulated phages were intrinsically embedded in

221 iron flocs thus making it difficult to achieve enough contrast between viral capsid and iron flocs

222 under the same instrumental condition for untreated phages. As seen in Figure S11A, due to the

223 presence of numerous electron-dense iron flocs, the contrast of these images was too low to clearly

224 outline damaged phages and their structural deformation. Nonetheless, it should be noted that such

225 images were used for capsid thickness measurement which justified the capsid thickness

226 comparison shown in Figures 4H and 4I in the main manuscript.

227

Meanwhile, higher defocusing provided more contrast between viral capsid and iron floc

228 background clearly depicting capsid damages (Figure S11B). However, it also resulted in a large

229 shift of intact capsid thickness from $2.4 \mathrm{~nm}$ to $4.0 \mathrm{~nm}$ (Figure S12) demonstrating its artifactual

230 influence on quantitative measurement.

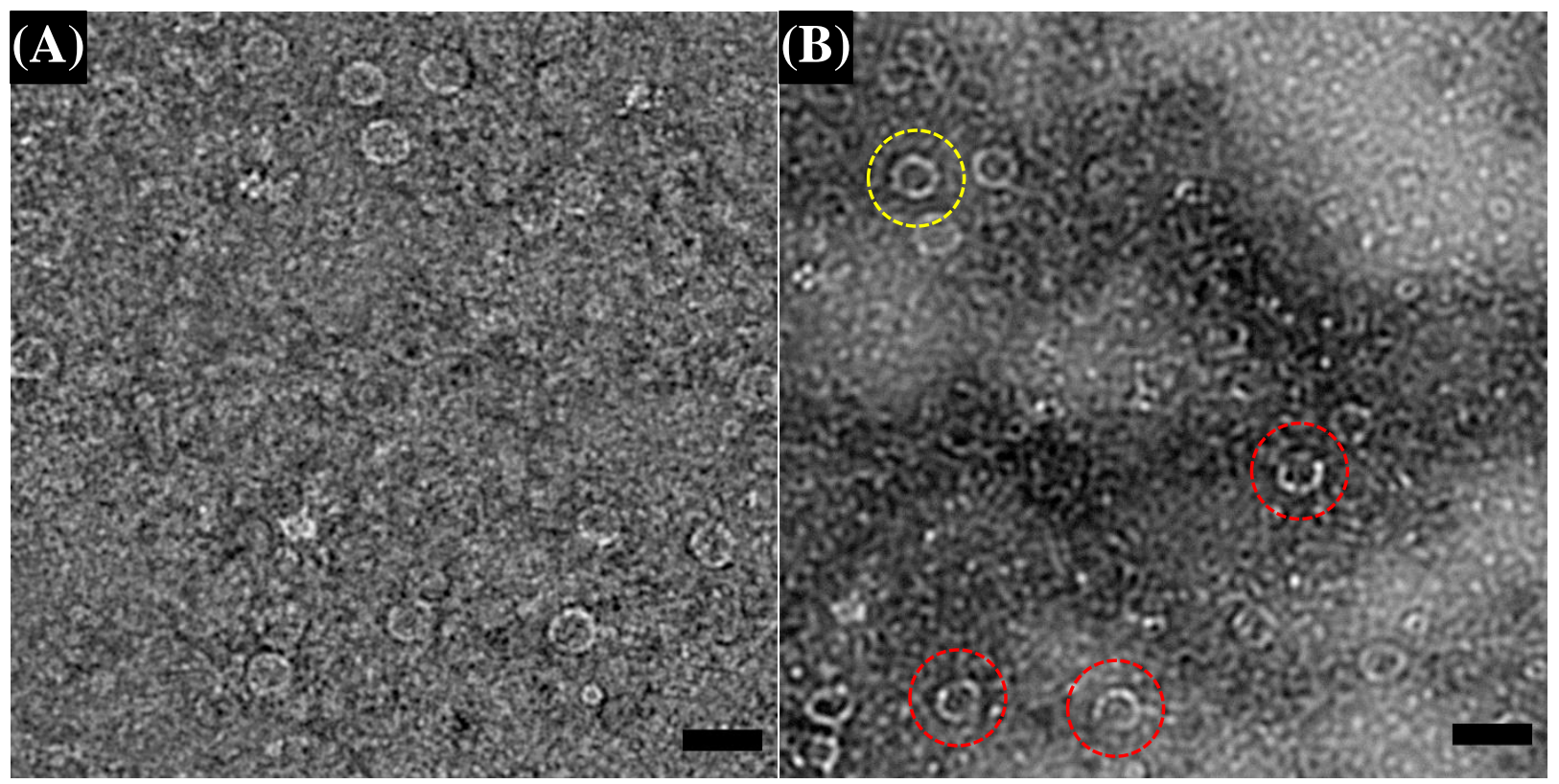

232 Figure S11. Visualization of phages in iron flocs with low (A) and high defocusing (B). The use of high

233 defocusing generated electron micrographs that clearly differentiated relatively intact virion (yellow-dotted

234 circle) and structurally-deformed virions (red-dotted circles). Scale bars equal $50 \mathrm{~nm}$. 


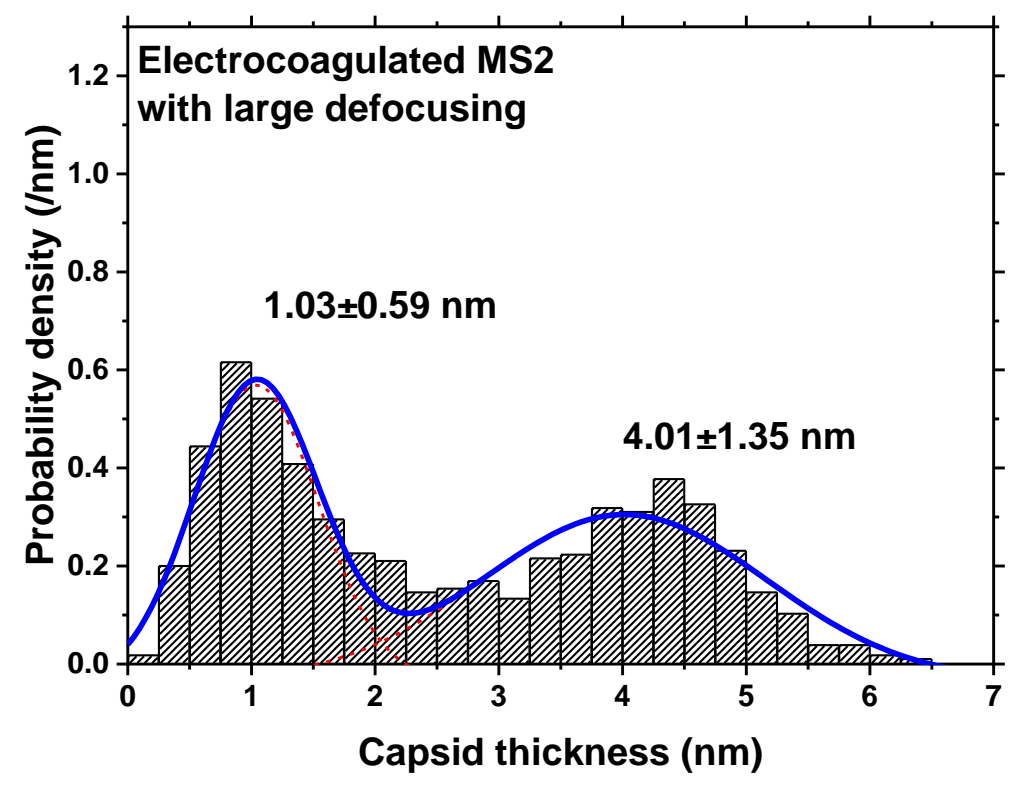

Figure S12. Artifactual effect of defocusing on capsid thickness measurement. 
237 Section S14. FTIR Analysis of Untreated and Coagulated MS2. Experiments and instrumental

238 measurements were replicated and reproducibility was estimated by calculating correlation 239 coefficients using QCheck function embedded in OMNIC software (Thermo Scientific) at $4 \mathrm{~cm}^{-1}$

240 resolution (Figure S13). ${ }^{53,54}$ Although visually recognizable local discrepancies (e.g. shape of the

241 shoulder of untreated MS2 spectrum around $1550 \mathrm{~cm}^{-1}$ ) were found, replicate spectra were

242 statistically similar resulting in correlation coefficients of 0.88-0.96 (among triplicates of untreated

243 MS2), 0.78 (between duplicates after $\mathrm{FeCl}_{3}$ ), and 0.73 (between duplicates after EC) according to

244 the criteria by $\quad$ Thermo $\quad$ Scientific

245 (htps://kb.unitylabservices.com/kb/article?ArticleId=349327\&source=Article \&c=13142\&cid=12

246 825). Importantly, the replicated spectra featured common important characteristics. For example,

247 electrocoagulated MS2 resulted in a slightly different spectrum in each trial, but all spectra showed

248 a significant decrease in amide II region and evolution of new peaks above $1700 \mathrm{~cm}^{-1}$ compared

249 with untreated and chemically coagulated MS2. Therefore, the average of replicate spectra was

250 presented in Figure 5 of the main manuscript and Figure S14 shown below.

251 For probing secondary structure changes, the amide I region was exclusively analyzed as it has

252 been known to be dominantly affected by the structure of the protein backbone and, thus, by

253 characteristics of hydrogen bonds between $\mathrm{C}=\mathrm{O}$ and $\mathrm{N}-\mathrm{H}$ groups (not by the types of the side

254 chain) which largely determine protein secondary structures. ${ }^{55-58}$ Peak positions (within amide I

255 region) of different secondary structures have been examined and documented based on

256 empirical/experimental data with known structure protein molecules with a support of theoretical

257 calculation. ${ }^{58-60}$ In this study, amide I region was decomposed into individual peaks that were

258 identified by taking a second derivative. Revealed peaks were assigned to specific secondary

259 structures based on literature values (see Table S2 and S3). 

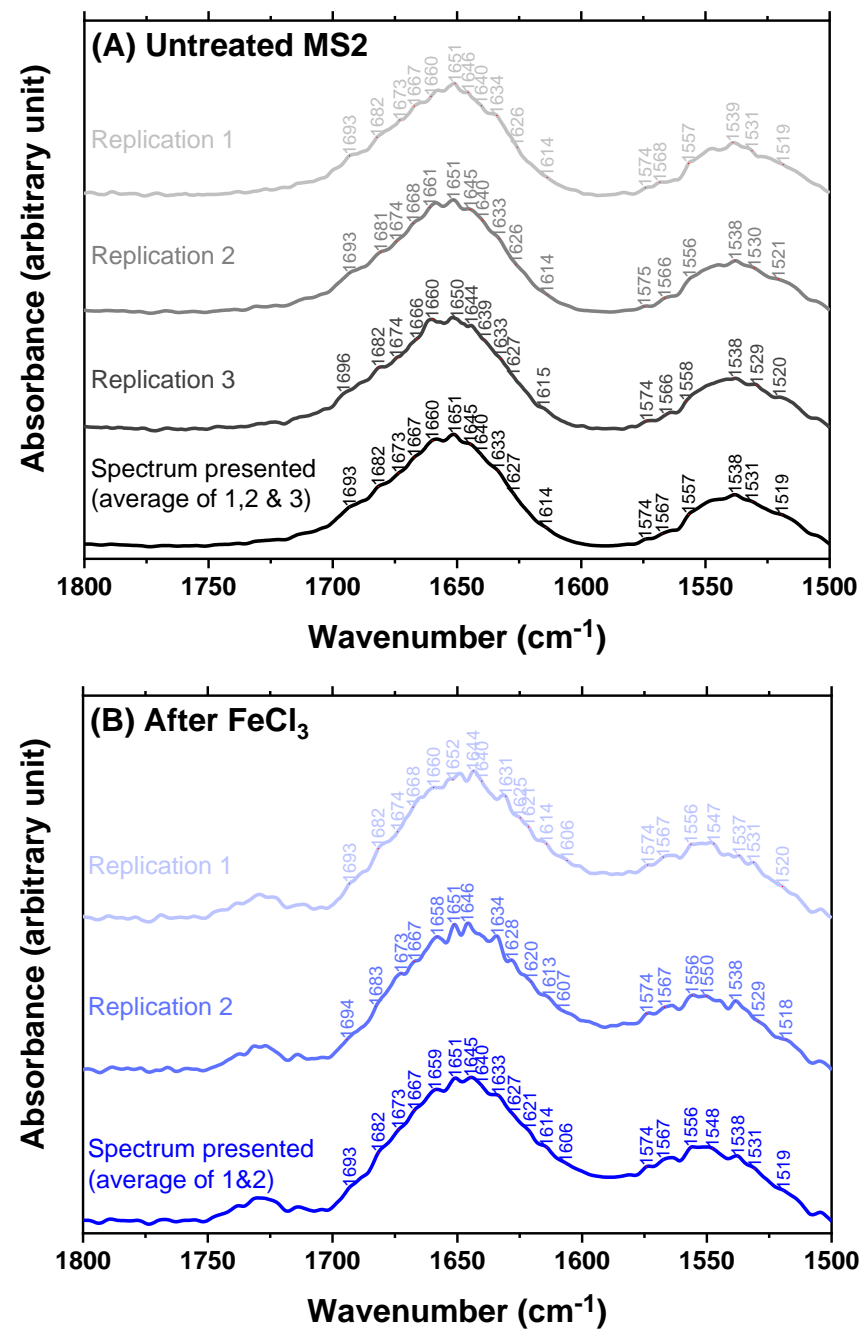

261

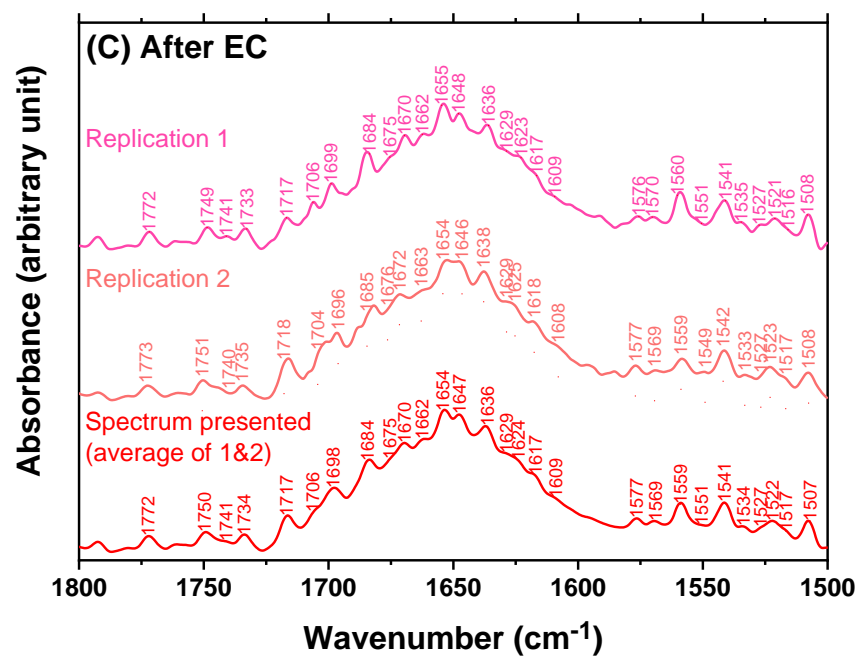

Figure S13. Reproducibility of FTIR spectrum of untreated (A), chemically coagulated (B), and electrocoagulated MS2 (C). Correlation coefficient among replicated spectra were found to be $0.88-0.96$, 0.78 , and 0.73 for untreated MS2, after $\mathrm{FeCl}_{3}$, and after EC, respectively. 


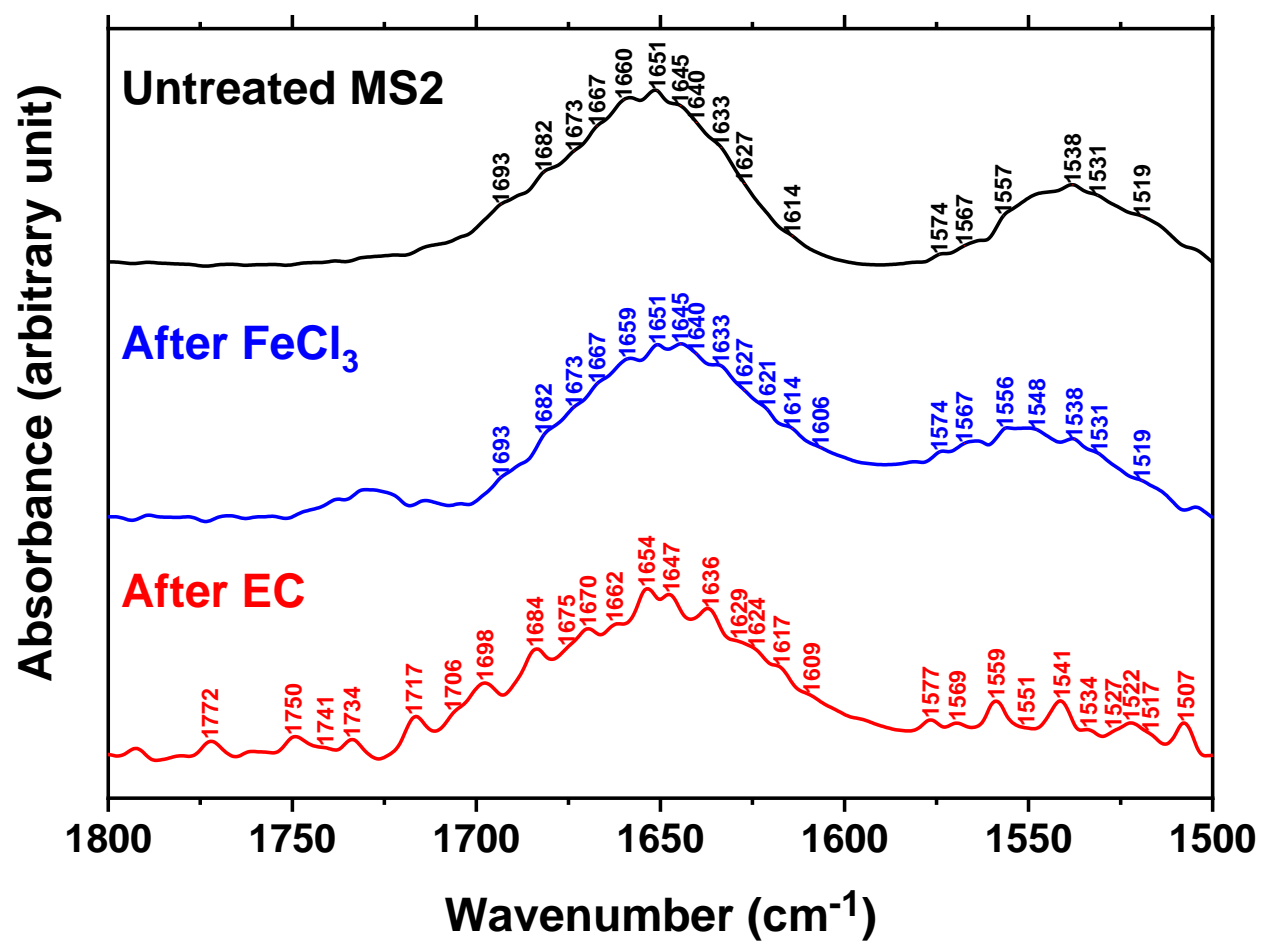

Figure S14. Comparison of untreated and coagulated MS2 with complete peak identifications.

268 Table S2. Identified FTIR band positions and corresponding assignments. ${ }^{55-57,61-63}$

\begin{tabular}{cl}
\hline Wavenumber $\left(\mathbf{c m}^{-1}\right)$ & \\
\hline 1772 & Carbonyl groups \\
\hline 1750 & Carbonyl groups \\
\hline $1743,1740,1734$ & Aliphatic aldehyde \\
\hline 1717,1706 & Aliphatic ketone \\
\hline 1700 & Aromatic ketone \\
\hline 1698 & $\mathrm{C}_{2}=$ O Guanine \\
\hline 1693 & High frequency of $\beta$-sheet \\
\hline 1684 & Disordered structure, non-hydrogen bonded \\
\hline 1682 & Unordered random coils and turns \\
\hline $1675 \sim 1667$ & Turns \\
\hline 1662 & Disordered structure \\
\hline $1660 \sim 1651$ & $\alpha$-helix \\
\hline 1647,1645 & Random coils and turns \\
\hline $1640 \sim 1627$ & $\beta$-sheet \\
\hline $1624 \sim 1614$ & Aggregated strand, intermolecular $\beta$-sheet \\
\hline 1609 & Gln, $\delta\left(\mathrm{NH}_{2}\right)$ \\
\hline $1579 \sim 1574$ & Asp $v_{\text {as }}\left(\mathrm{COO}^{-}\right)$ \\
\hline
\end{tabular}




\begin{tabular}{cl}
\hline 1577,1574 & $\mathrm{C}=\mathrm{N}$ Adenine \\
\hline 1569,1567 & Ring base \\
\hline 1559 & Ring base or Glu, $v_{\text {as }}\left(\mathrm{COO}^{-}\right)$ \\
\hline $1557 \sim 1551$ & Ring base \\
\hline 1548 & Amide II \\
\hline 1541 & Amide II, $\beta$-sheet, $v(\mathrm{~N}-\mathrm{H})$ \\
\hline 1538 & Stretching $\mathrm{C}=\mathrm{N}, \mathrm{C}=\mathrm{C}$ \\
\hline 1534 & Amide II, modified guanine, $v(\mathrm{C}=\mathrm{N}), v(\mathrm{C}=\mathrm{C})$ \\
\hline 1531 & Stretching $\mathrm{C}=\mathrm{N}, \mathrm{C}=\mathrm{C}$ \\
\hline 1527 & Lys, $\delta_{s}\left(\mathrm{NH}_{3}{ }^{+}\right)$ \\
\hline 1522 & Stretching $\mathrm{C}=\mathrm{N}, \mathrm{C}=\mathrm{C}$ \\
\hline 1519 & Tyr-OH, $v(\mathrm{CC}), \delta(\mathrm{CH})$ \\
\hline 1517 & Amide II \\
\hline 1507 & Trp, $v(\mathrm{CN}), \delta(\mathrm{CH}), \delta(\mathrm{NH})$ \\
\hline
\end{tabular}
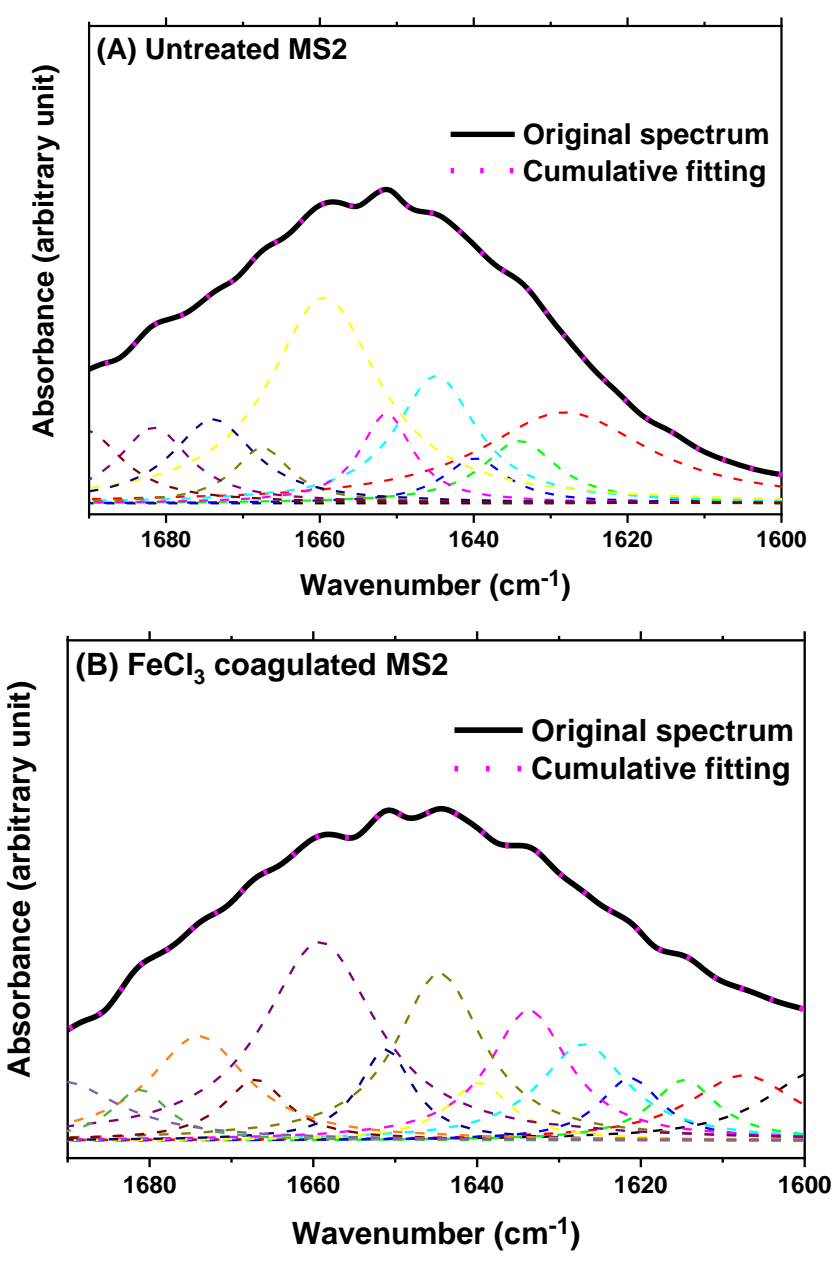


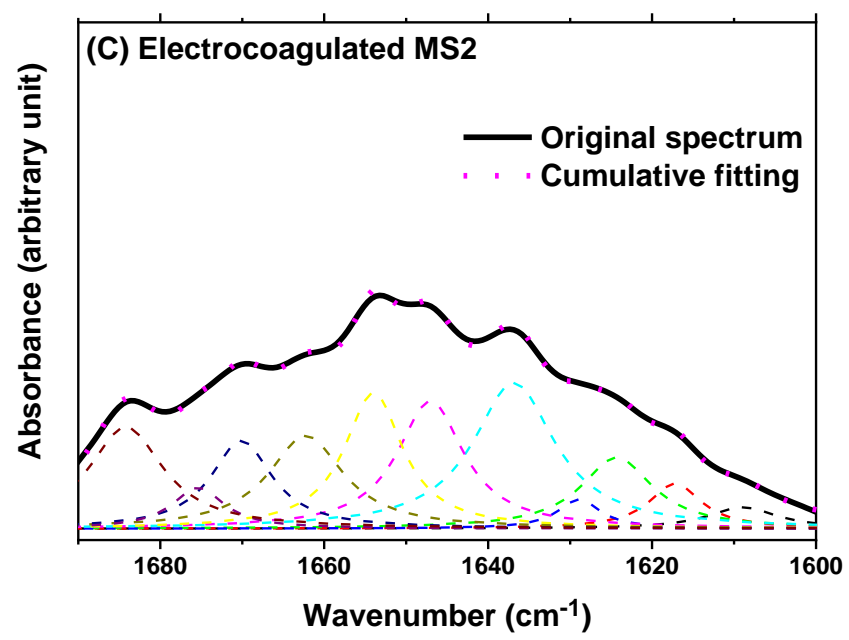

272 Figure S15. Decomposition of FTIR spectrum of untreated (A), $\mathrm{FeCl}_{3}$ coagulated (B), and 273 electrocoagulated MS2 (C).

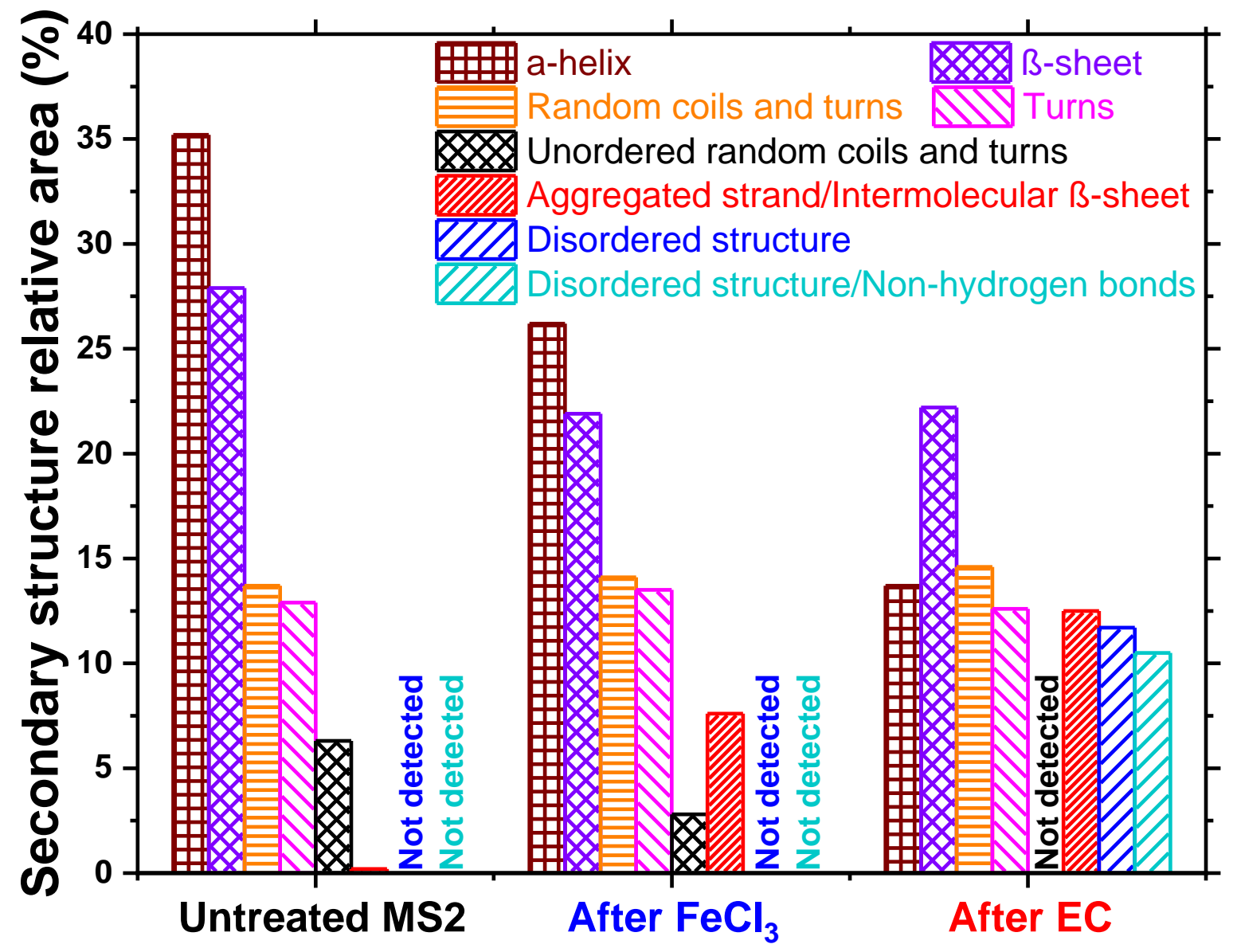

275 Figure S16. Comparison of relative secondary structure areas before and after conventional coagulation 276 and electrocoagulation. 
Table S3. Comparison of secondary structure relative areas of untreated and coagulated MS2 phage.

\begin{tabular}{|c|c|c|c|c|c|c|}
\hline \multirow[b]{2}{*}{ Secondary structure } & \multicolumn{2}{|c|}{ Untreated MS2 } & \multicolumn{2}{|c|}{$\mathrm{Fe}(\mathrm{III})$ or $\mathrm{FeCl}_{3}$-coagulated MS2 } & \multicolumn{2}{|c|}{ Electrocoagulated MS2 } \\
\hline & $\begin{array}{c}\text { Wavenumber } \\
\left(\mathrm{cm}^{-1}\right)\end{array}$ & $\begin{array}{c}\text { Relative area } \\
(\%)\end{array}$ & $\begin{array}{l}\text { Wavenumber } \\
\left(\mathbf{c m}^{-1}\right)\end{array}$ & $\begin{array}{c}\text { Relative area } \\
(\%)\end{array}$ & $\begin{array}{c}\text { Wavenumber } \\
\left(\mathrm{cm}^{-1}\right)\end{array}$ & $\begin{array}{c}\text { Relative area } \\
(\%)\end{array}$ \\
\hline \multirow{2}{*}{$\begin{array}{l}\text { Aggregated strand, } \\
\text { Intermolecular } \beta \text {-sheet }\end{array}$} & \multirow{2}{*}{1614} & \multirow{2}{*}{0.2} & 1614 & 3.8 & 1617 & 4.0 \\
\hline & & & 1621 & 3.8 & 1624 & 8.5 \\
\hline \multirow{3}{*}{$\beta$-sheet } & 1627 & 17.8 & 1627 & 8.1 & 1629 & 2.2 \\
\hline & 1633 & 6.2 & 1633 & 10.1 & \multirow[t]{2}{*}{1636} & \multirow[t]{2}{*}{20.0} \\
\hline & 1640 & 3.9 & 1640 & 3.7 & & \\
\hline Random coils and turns & 1645 & 13.7 & 1645 & 14.1 & 1647 & 14.6 \\
\hline \multirow{2}{*}{$\alpha$-helix } & 1651 & 6.5 & 1651 & 5.0 & \multirow{2}{*}{1654} & \multirow{2}{*}{13.7} \\
\hline & 1660 & 28.7 & 1659 & 21.2 & & \\
\hline Disordered structure & - & - & - & - & 1662 & 11.7 \\
\hline \multirow{2}{*}{ Turns } & 1667 & 4.2 & 1667 & 3.9 & 1670 & 9.0 \\
\hline & 1673 & 8.7 & 1673 & 9.6 & 1675 & 3.6 \\
\hline $\begin{array}{l}\text { Unordered random } \\
\text { coils and turns }\end{array}$ & 1682 & 6.3 & 1682 & 2.8 & - & - \\
\hline $\begin{array}{l}\text { Disordered structure, } \\
\text { non-hydrogen bonded }\end{array}$ & - & - & - & - & 1684 & 10.5 \\
\hline \multirow{3}{*}{ Etc. } & 1693 & 3.8 & 1598 & 3.2 & 1609 & 2.2 \\
\hline & & & 1606 & 5.3 & & \\
\hline & & & 1691 & 5.4 & & \\
\hline
\end{tabular}



$\mathbf{F e C l}_{2}$, and $\mathbf{F e C l}_{3}$ coagulation. In $\mathrm{FeCl}_{3}$ coagulation, nearly all (> 8-log) of the phages sorbed onto iron flocs (red line in Figure S17B), which we could completely extract and enumerate using the plaque assay (also see SI Figure S3 and S4). Corresponding infective virus concentrations in the bulk water were $100-1,000$ times lower ranging between $10^{5}-10^{6} \mathrm{PFU} / \mathrm{mL}$ in Figure S17A

284 demonstrating highly effective coagulation. This corresponds to a total iron dosage of $10 \mathrm{mg} / \mathrm{L}$ and solution $\mathrm{pH}$ of 6.4. Since the sum of infective viruses in the flocs and water column was the same as what was added at the beginning of the experiment it can be concluded that viruses were not inactivated during direct $\mathrm{FeCl}_{3}$ coagulation.
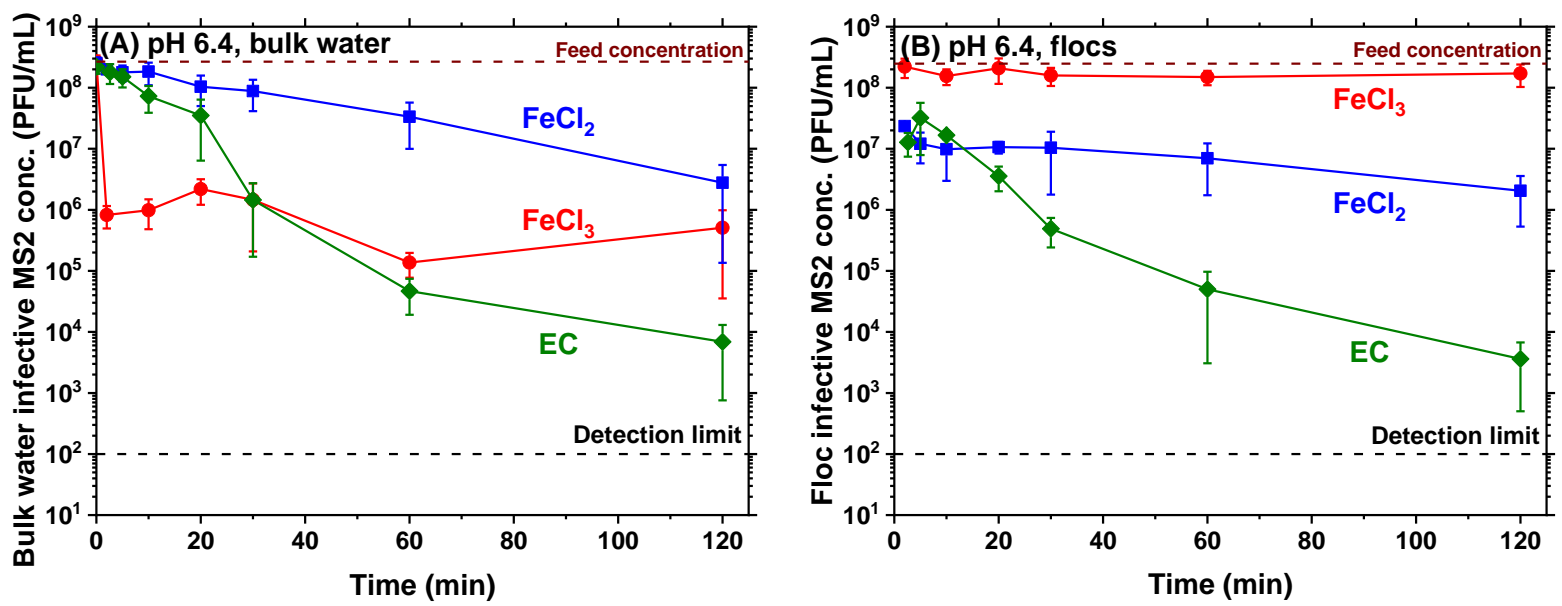

Figure S17. Comparison of infective virus concentration profiles by $\mathrm{FeCl}_{2}, \mathrm{FeCl}_{3}$, and electrocoagulation. Experimental conditions were $\mathrm{pH} 6.4$ and $10 \mathrm{mg} / \mathrm{L}$ total iron dosage. 

during Electrolysis. Figure S18 shows dissolved oxygen (DO) changes over time under various conditions when total $10 \mathrm{mg} / \mathrm{L}$ of iron was dosed either by external chemical addition or via 294 electrolysis, in the presence and absence of a chelating agent (1,10-phenanthroline), and at two $\mathrm{pH}$ values of interest (6.4 and 8.2). When $\mathrm{FeCl}_{2}$ was added at $\mathrm{pH} 6.4$, DO was gradually consumed demonstrating only a slow oxidation of Fe(II) (black solid line). However, when Fe(II) was 297 complexed at the same $\mathrm{pH}$ by adding 1,10-phenathroline (4.4 mM, black dotted line), DO 298 concentration remained unchanged. ${ }^{64}$ When EC was performed at $\mathrm{pH} 8.2$ (blue solid line), a rapid 299 decrease of DO during the electrolysis was observed, similar to $\mathrm{FeCl}_{2}$ at $\mathrm{pH}$ 8.2. Considering that $300 \mathrm{H}_{2} \mathrm{O}_{2}$ was not detected at $\mathrm{pH} 8.2$ (Figure 7B in the main manuscript), this behavior is indicative of 301 fast oxidation of $\mathrm{Fe}(\mathrm{II})$ released during electrolysis by $\mathrm{DO}$ at high $\mathrm{pH}^{65}$ as expected. In contrast, 302 additional DO consumption was observed in EC at $\mathrm{pH} 6.4$ (red solid line) indicating that DO was 303 consumed by cathodic $\mathrm{H}_{2} \mathrm{O}_{2}$ production as well. Addition of 1,10-phenanthroline to EC at $\mathrm{pH} 6.4$ 304 further confirms the extra DO consumption during the electrolysis. Even when this chelating agent was added (red dotted line), approximately $15 \%$ of the DO was consumed.

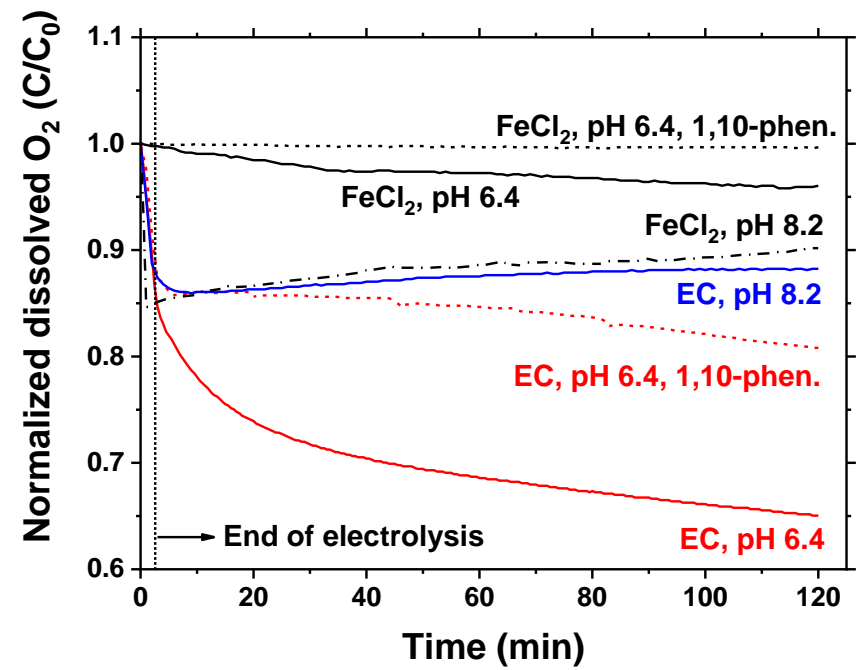

Figure S18. Dissolved oxygen consumption under various conditions at total iron dosage of $10 \mathrm{mg} / \mathrm{L}$. 
Inactivation. Figure S19 compares the infective MS2 concentration in bulk water and flocs when EC was performed with and without addition of dimethyl sulfoxide (DMSO). DMSO is known to

311 scavenge ${ }^{\circ} \mathrm{OH}$ and $\mathrm{Fe}(\mathrm{IV}),{ }^{66}$ but not $\mathrm{H}_{2} \mathrm{O}_{2} \cdot{ }^{67}$ In our experiments, the effect of DMSO was found to

312 be negligible in bulk phase which is consistent with previous studies where inactivation of MS2

313 by Fenton's and Fenton-like reaction was investigated separate from electrolysis. ${ }^{4,68}$ This result

314 indicates that only ${ }^{\circ} \mathrm{OH} / \mathrm{Fe}(\mathrm{IV})$ present in the close proximity near and/or on the surface of MS2

315 are effective in bulk inactivation. This can be attributed to a rapid consumption of ${ }^{\circ} \mathrm{OH} / \mathrm{Fe}(\mathrm{IV})$ by

316 reacting with other species such as Fe(II) (Equations S11 and S12 in Table S4 below), and to

317 possible complexation of $\mathrm{Fe}(\mathrm{II})$ with coat protein of MS2. ${ }^{69} \mathrm{DMSO}$ also did not affect inactivation

318 on floc surfaces. This might be because floc inactivation is triggered by Fe(II) adsorbed on the floc

319 as it has been shown that $\mathrm{Fe}(\mathrm{II})$ adsorbs onto iron (oxy)hydroxide. ${ }^{70}$
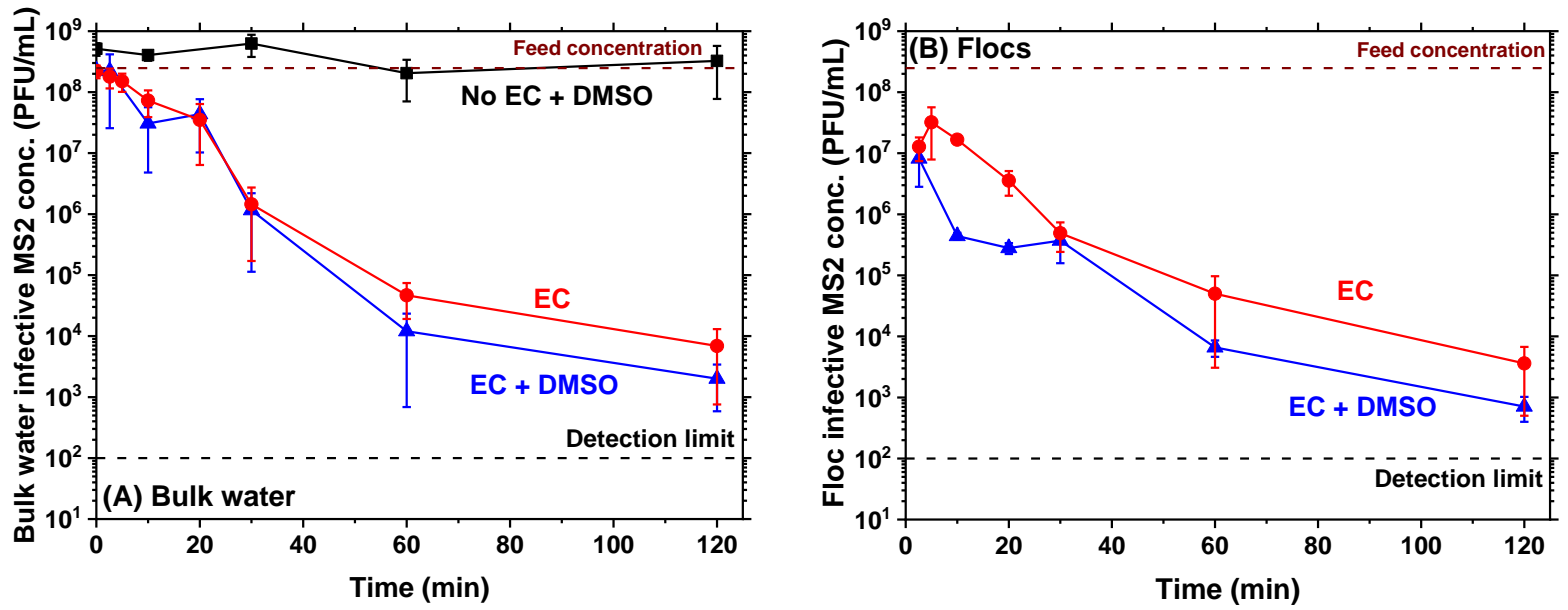

321 Figure S19. Negligible effect of DMSO $(25 \mathrm{mM})$ on MS2 control by EC at pH 6.4 and $10 \mathrm{mg} / \mathrm{L}$ total iron. 
322 Section S18. Total Inactivation at Different pH. In order to clarify $\mathrm{pH}$ dependence of virus

323 inactivation during $\mathrm{EC}$, total inactivation at each $\mathrm{pH}$ and dose over time was determined by

324 dividing the initial concentration $\left(\mathrm{N}_{0}\right)$ by the sum of infective virus concentrations in bulk water

325 and flocs $(\mathrm{N})$. These results are shown below in Figure S20. The left panel shows a continuous

326 increase in total inactivation at $\mathrm{pH} 6.4$ demonstrating that viruses lost infectivity during the entire

327 2-hour flocculation period. In contrast at $\mathrm{pH} 8.2$ (right panel), inactivation was not only

328 significantly lower, but was only observed during electrolysis and the initial period of flocculation

329 consistent with Fenton's chemistry.
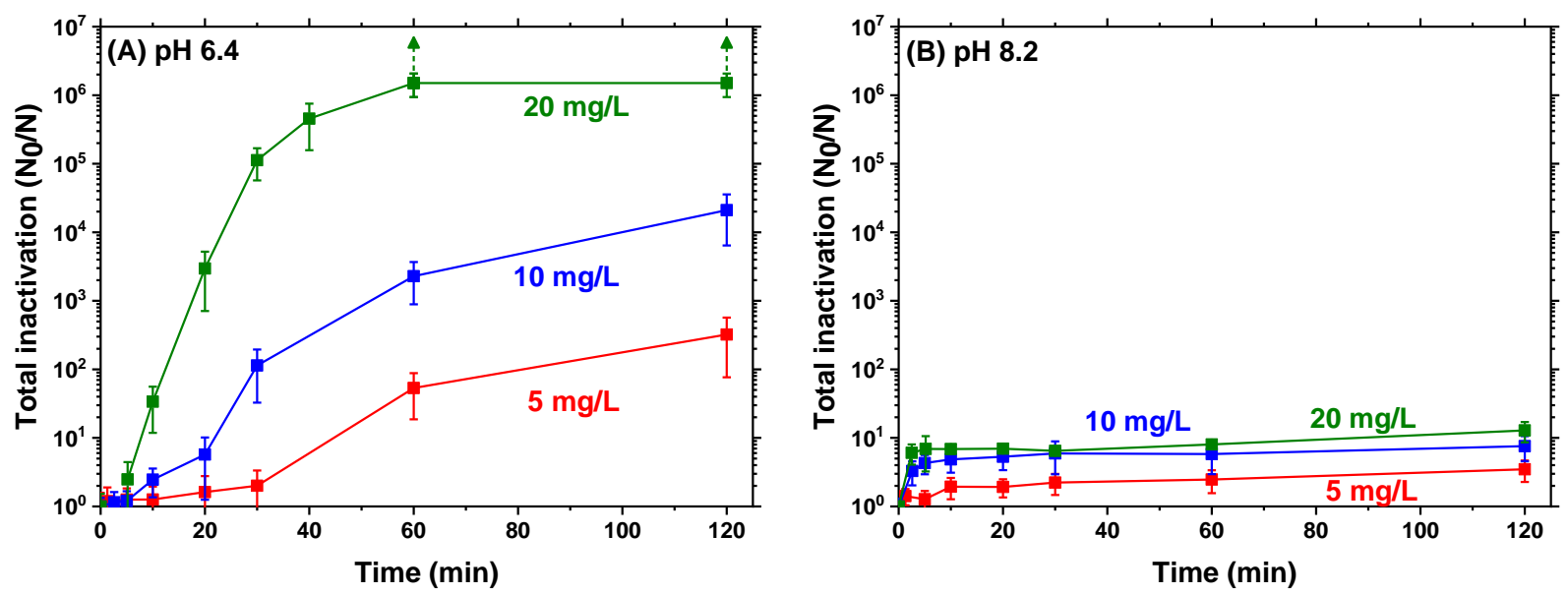

Figure S20. Total inactivation of MS2 phages during EC at pH 6.4 and $\mathrm{pH} 8.2$. 


\section{Section S19. Control Experiments to Obtain Clues Underlying Chemical Inactivation.}

333 Several other controls were also performed, and measurements were made to identify potentially

334 responsible species in the context of $\mathrm{Fe}(\mathrm{II})$ and Fenton's chemistry. For example, $\mathrm{H}_{2} \mathrm{O}_{2}$ alone did

335 not impact MS2 viability over the 2-hour duration of experiments (Figure S22). Further,

336 inactivation was completely suppressed during $\mathrm{FeCl}_{2}$ coagulation and $\mathrm{EC}$ at $\mathrm{pH} 6.4$ by (i) chelating

$337 \mathrm{Fe}(\mathrm{II})$ using 1,10-phenanthroline ${ }^{71}$ or (ii) $\mathrm{N}_{2}$ purging to deoxygenate the feed water ${ }^{39}$ and 338 consequently prevent Fe(II) oxidation (Figure S23). These controls demonstrate unequivocally 339 that both $\mathrm{Fe}(\mathrm{II})$ and dissolved oxygen species needed to be present simultaneously to inactivate $340 \mathrm{MS} 2$ at $\mathrm{pH}$ 6.4. A role of $\mathrm{H}_{2} \mathrm{O}_{2}$ was further clarified by adding sodium sulfite as a $\mathrm{H}_{2} \mathrm{O}_{2}$ scavenger 341 at the end of electrolysis (Figure S24). Negligible inactivation solely by $25 \mu \mathrm{M}$ of $\mathrm{H}_{2} \mathrm{O}_{2}$ at both $342 \mathrm{pH}$ and significant inhibition of inactivation due to sodium sulfite signifies the involvement of 343 additionally generated $\mathrm{H}_{2} \mathrm{O}_{2}$ in inactivation along with $\mathrm{Fe}(\mathrm{II})$ enhancing Fenton's reaction.

344 Insignificant Impact of ${ }^{\bullet} \mathbf{O}_{2}{ }^{-}$on MS2 Inactivation in EC. The addition of $5 \mathrm{U} / \mathrm{mL}$ superoxide

345 dismutase (SOD) as a scavenger for superoxide radical $\left({ }^{\circ} \mathrm{O}_{2}^{-}\right)^{4}$ resulted only in a marginal 346 difference in infective MS2 concentration in bulk water and flocs. In other words, the superoxide 347 radical was not an effective disinfectant in our experiments. 

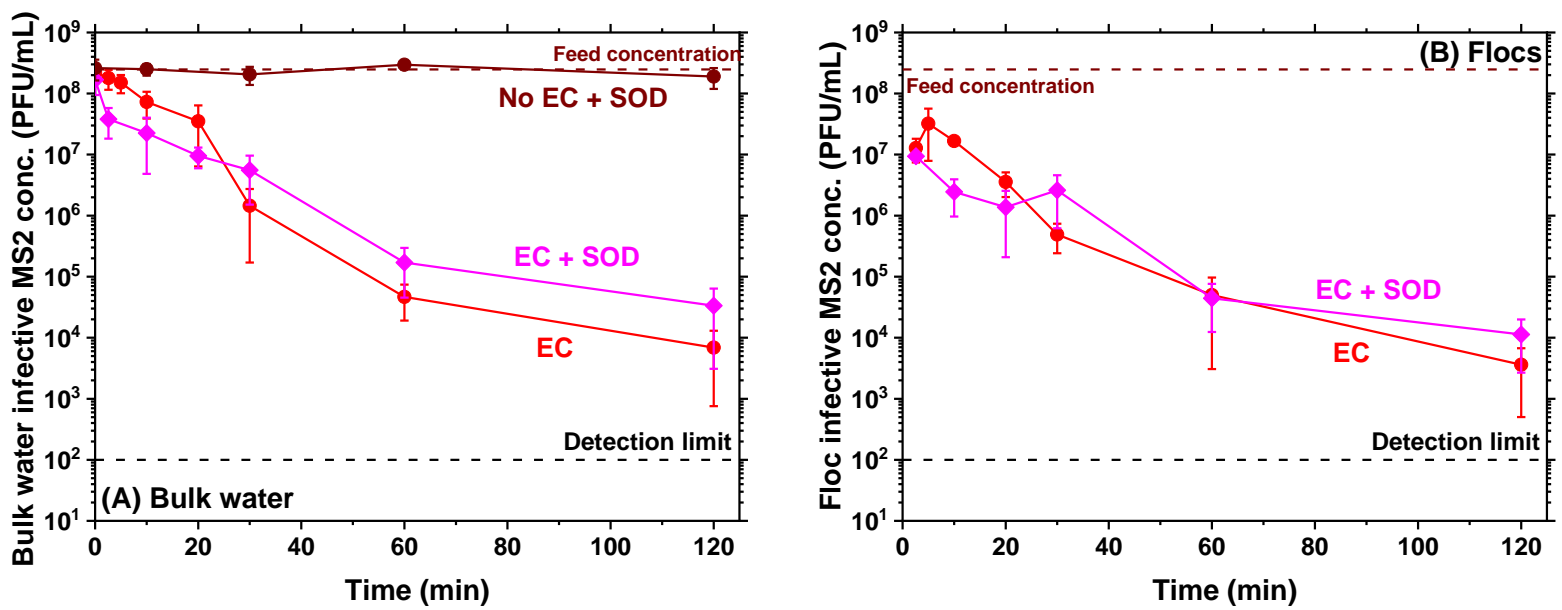

Figure S21. Negligible effect of ${ }^{\bullet} \mathrm{O}_{2}{ }^{-}$on MS2 inactivation during EC ( $\mathrm{pH} 6.4,10 \mathrm{mg} / \mathrm{L}$ total iron) proven by addition of superoxide dismutase.

Negligible Inactivation of MS2 by $\mathbf{H}_{2} \mathrm{O}_{2}$. Changes in infective MS2 concentrations solely by adding $25 \mu \mathrm{M}(\sim 850 \mu \mathrm{g} / \mathrm{L})$ of $\mathrm{H}_{2} \mathrm{O}_{2}$ was monitored at both $\mathrm{pH}$ values. As shown below as blue lines in Figure S22, inactivation was not observed at $\mathrm{pH} 6.4$ and 8.2, as expected from previous publications. ${ }^{4,68}$ Also, in the absence of $\mathrm{Fe}(\mathrm{II}), \mathrm{H}_{2} \mathrm{O}_{2}$ concentrations remained relatively constant as shown as green lines corresponding to the second (right hand side) y-axis.
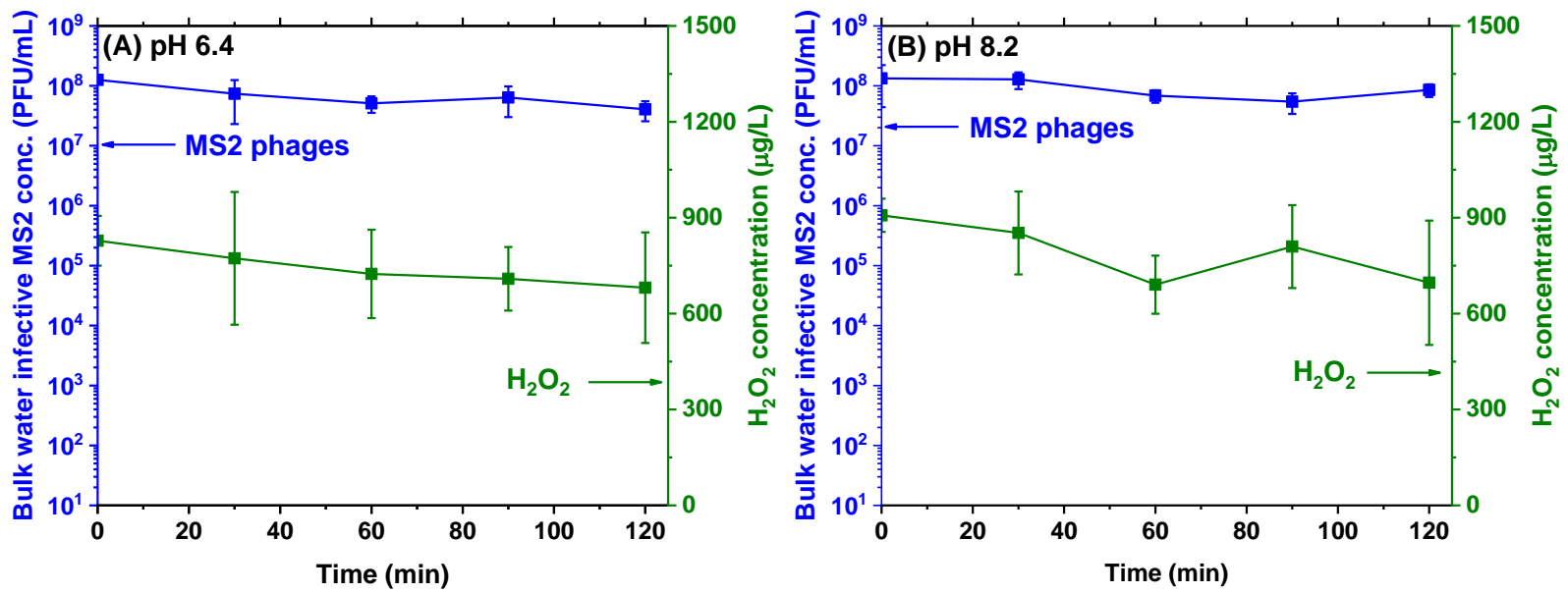

Figure S22. Negligible effect of $\mathrm{H}_{2} \mathrm{O}_{2}$ on MS2 phage inactivation.

Combined Role of $\mathbf{F e}(\mathrm{II})$ and $\mathrm{O}_{2}$ in MS2 Inactivation. Viruses were monitored after adding $\mathrm{FeCl}_{2}$ and $\mathrm{EC}$ at $\mathrm{pH} 6.4$ and $10 \mathrm{mg} / \mathrm{L}$ total iron in the presence of 1,10 -phenanthroline ${ }^{4,43}$ or 
361 deaeration ${ }^{43}$ to screen out the role of Fe(II) and dissolved oxygen, respectively. As seen in Figure 362 S23, inactivation of MS2 phage was substantially inhibited by addition of 1,10-phenanthroline and 363 deaeration in $\mathrm{FeCl}_{2}$ and $\mathrm{EC}$. This result indicates that virus inactivation by $\mathrm{FeCl}_{2}$ and $\mathrm{EC}$ requires 364 both $\mathrm{Fe}(\mathrm{II})$ and dissolved oxygen to be present concurrently.
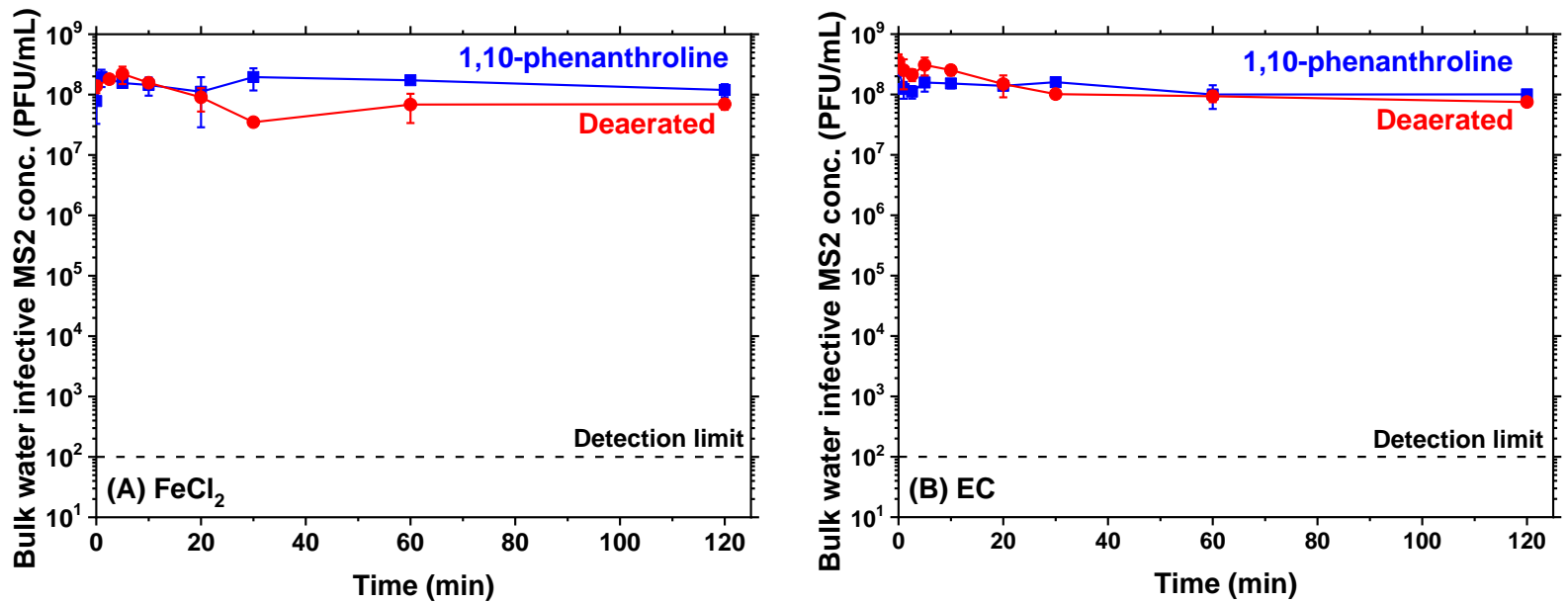

Figure S23. Suppression of virus inactivation due to $\mathrm{Fe}(\mathrm{II})$ complexation with 1,10-phenanthroline (4.4 $\mathrm{mM}$ ) and deaeration in (A) $\mathrm{FeCl}_{2}$ and (B) EC.

Important Role of $\mathrm{H}_{2} \mathrm{O}_{2}$ in Inactivation. The addition of $25 \mathrm{mM} \mathrm{Na} 2 \mathrm{SO}_{3}$ as a $\mathrm{H}_{2} \mathrm{O}_{2}$ scavenger at the end of electrolysis inhibited virus inactivation both in bulk solution and floc surfaces. This result signifies the involvement of additionally generated $\mathrm{H}_{2} \mathrm{O}_{2}$ in inactivation along with $\mathrm{Fe}(\mathrm{II})$, i.e. Fenton's reaction.
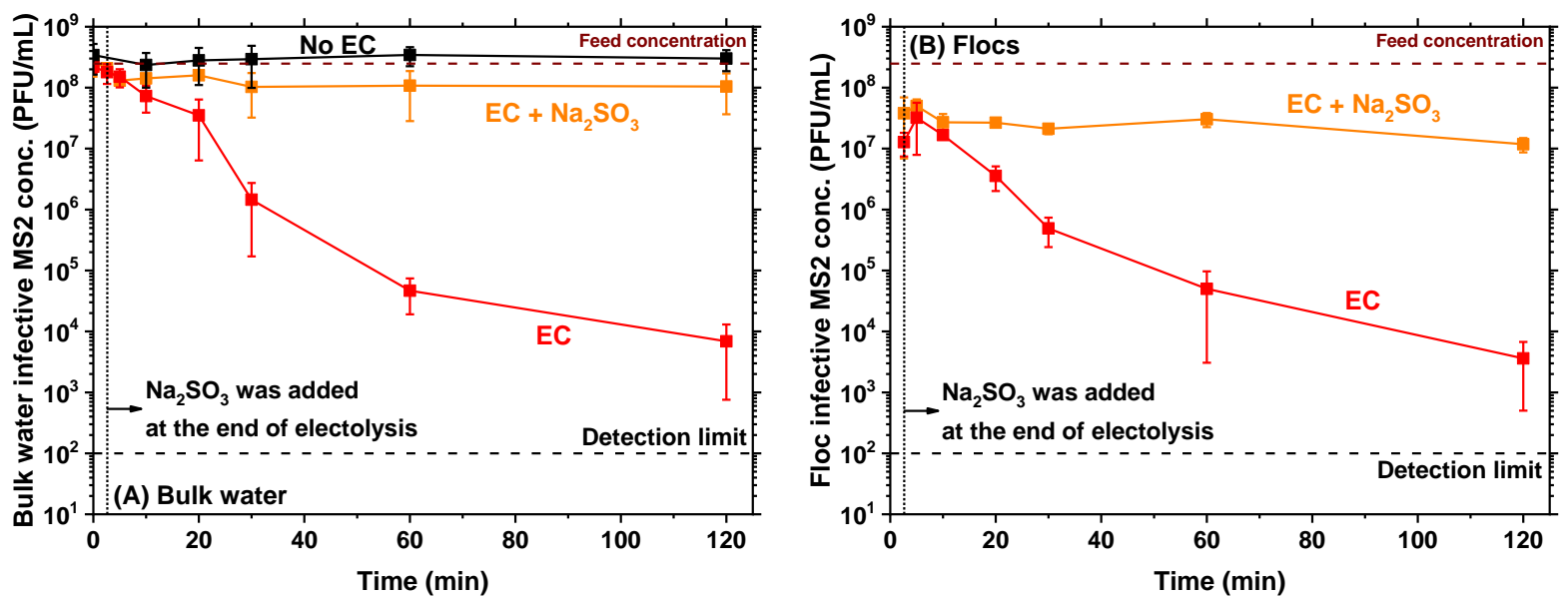

Figure S24. Inhibition of MS2 inactivation by $\mathrm{Na}_{2} \mathrm{SO}_{3}$ in $\mathrm{EC}$ ar $10 \mathrm{mg} / \mathrm{L}$ total iron and $\mathrm{pH} 6.4$. 
374 Free Chlorine Was Not Detected. In our previous study using aluminum EC of saline 375 solutions, free chlorine was detected and was attributed to minor amounts of inactivation. ${ }^{11}$ 376 Therefore, the possibility of free chlorine production during electrolysis in these experiments and 377 its potential contributions to inactivation was also investigated. In order to avoid interference by 378 other oxidants, the indophenol method was used to detect free chlorine where free chlorine is 379 converted to chloramine (HACH method 10241). In all experiments, free chlorine was not detected 380 during the electrolysis and flocculation presumably because chloride ion concentrations were low 381 unlike our earlier study. ${ }^{11}$ 

temporal profiles of viral RNA extracted from the bulk water (left panel) and flocs (right panel) at different total iron doses and $\mathrm{pH}$. The targeted genomic region was quantitatively measured via RT-qPCR in the negative control (no electrolysis, black line in Figure S25A) similar to the plaque assay in Figure 1 in the manuscript. Therefore, any genomic changes measured during EC could be reliably assigned to electrolysis products.
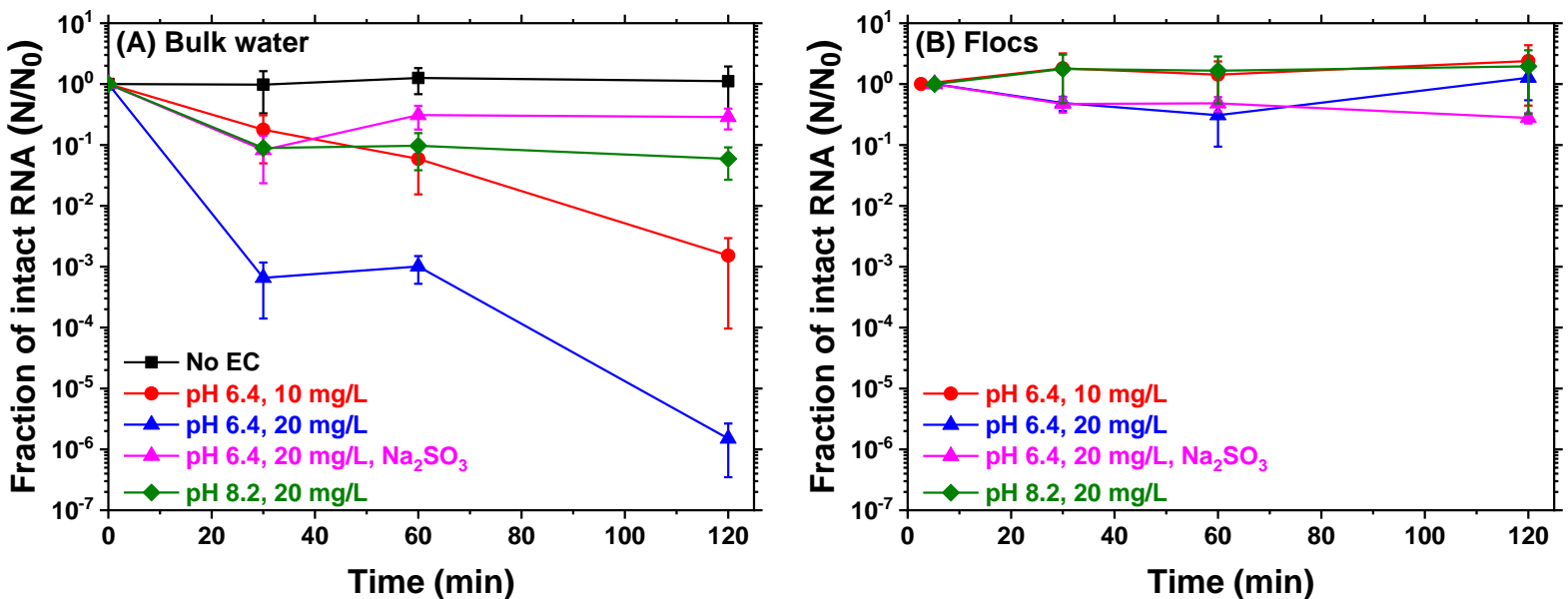

Figure S25. RNA measured in bulk water (left panel, A) and flocs (right panel, B) during EC. Error bars are one standard deviation of at least four measurements. $\mathrm{N}_{0}$ is the number of RNA copies measured immediately after adding viruses to the EC apparatus.

Electrocoagulation at $\mathrm{pH} 6.4$ reduced the fraction of intact RNA extracted from the bulk water over time and with total iron dosage (red and blue curves in Figure S25A). However, at pH 8.2 and $20 \mathrm{mg} / \mathrm{L}$ total iron, RNA decreased by only $\sim 1-\log$ in the first 30 minutes (green curve) remaining constant later on. As shown, significantly more RNA was lost at pH 6.4 compared with 8.2. These trends for viral RNA in the water column obtained via RT-qPCR are qualitatively similar to those of plaque assays but exhibit large differences in magnitude. For example, Figure S25A depicts a decrease of only 1.2-log RNA compared with 3.7-logs of total infectivity loss in Figure 1A for $10 \mathrm{mg} / \mathrm{L}$ total iron at 60 minutes and pH 6.4 in the manuscript. Substantially lower 
400 RNA loss compared with the plaque assay demonstrates that RT-qPCR targeting only a short 401 fragment (77 bp amplicon) underestimated trends obtained with infective virions. ${ }^{11,72-74}$

402 In contrast to the bulk water, viral ssRNA was consistently and quantitatively recovered from 403 the flocs showing only relatively minor changes throughout the 2-hour duration of all experiments 404 (Figure S25B). This suggests relatively stable behavior of the targeted genome region even 405 following MS2 uptake on iron flocs. In contrast, Figure 1B in the manuscript depicts significant 406 virus inactivation on flocs at $\mathrm{pH} 6.4$ using the plaque assay because lower amounts of phages were 407 recovered with time, i.e. all three curves had negative slopes. Therefore, virus behavior trends 408 during EC differed substantially depending on whether it was monitored by RT-qPCR or 409 infectivity assay both quantitatively and qualitatively. Presumptive oxidative modifications 410 inferred from Figure 5 in the manuscript and RNA loss in Figure S25A point to the presence of 411 chemical intermediates in solution. 


\section{Section S21. Electrochemical Reactions during EC.}

413 Table S1. Summary of electrochemical reactions in EC. , 22,75

\begin{tabular}{lll}
\hline Description & Reaction & \\
\hline Dissolution of ferrous iron from anode & $\mathrm{Fe}(0) \rightarrow \mathrm{Fe}(\mathrm{II})+2 \mathrm{e}^{-}$ & $(\mathrm{S} 2)$ \\
\hline Ferrous iron oxidation by dissolved $\mathrm{O}_{2}$ & $\mathrm{Fe}(\mathrm{II})+\mathrm{O}_{2} \rightarrow \mathrm{Fe}(\mathrm{III})+\cdot \mathrm{O}_{2}^{-}$ & $(\mathrm{S} 3)$ \\
\hline Ferrous iron oxidation by $\cdot \mathrm{O}_{2}^{-}$ & $\mathrm{Fe}(\mathrm{II})+\cdot \mathrm{O}_{2}^{-}+2 \mathrm{H}^{+} \rightarrow \mathrm{Fe}(\mathrm{III})+\mathrm{H}_{2} \mathrm{O}_{2}$ & $(\mathrm{~S} 4)$ \\
\hline Ferric iron reduction by $\cdot \mathrm{O}_{2}^{-}$ & $\mathrm{Fe}(\mathrm{III})+\mathrm{O}_{2}^{-} \rightarrow \mathrm{Fe}(\mathrm{II})+\mathrm{O}_{2}$ & $(\mathrm{~S} 5)$ \\
\hline Fenton's reaction & $\mathrm{Fe}(\mathrm{II})+\mathrm{H}_{2} \mathrm{O}_{2} \rightarrow \mathrm{Fe}(\mathrm{III})+\cdot \mathrm{OH}+\mathrm{OH}^{-}$ & $(\mathrm{S} 6)$ \\
\cline { 2 - 3 } & $\mathrm{Fe}(\mathrm{II})+\mathrm{H}_{2} \mathrm{O}_{2} \rightarrow \mathrm{Fe}(\mathrm{IV}) \mathrm{O}^{2+}+\mathrm{H}_{2} \mathrm{O}$ & $(\mathrm{S} 7)$ \\
\hline $\mathrm{H}_{2(\mathrm{~g})}$ production on cathode & $2 \mathrm{H}^{+}+2 \mathrm{e}^{-} \rightarrow \mathrm{H}_{2(\mathrm{~g})}$ & $(\mathrm{S} 8)$ \\
\hline $\mathrm{H}_{2} \mathrm{O}_{2}$ production on cathode & $2 \mathrm{H}^{+}+\mathrm{O}_{2}+2 \mathrm{e}^{-} \rightarrow \mathrm{H}_{2} \mathrm{O}_{2}$ & $(\mathrm{~S} 9)$ \\
\hline Iron floc formation & $\mathrm{Fe}(\mathrm{III})+3 \mathrm{H}_{2} \mathrm{O} \rightarrow \mathrm{Fe}(\mathrm{OH})_{3(\mathrm{am})}+3 \mathrm{H}^{+}$ & $(\mathrm{S} 10)$ \\
\hline Consumption of Fenton's reaction & $\cdot \mathrm{OH}+\mathrm{Fe}(\mathrm{II}) \rightarrow \mathrm{OH}{ }^{-}+\mathrm{Fe}(\mathrm{III})$ & $(\mathrm{S} 11)$ \\
\cline { 2 - 3 } products & $\mathrm{Fe}(\mathrm{IV}) \mathrm{O}^{2+}+\mathrm{Fe}(\mathrm{II})+2 \mathrm{H}^{+} \rightarrow 2 \mathrm{Fe}(\mathrm{III})+\mathrm{H}_{2} \mathrm{O}$ & $(\mathrm{S} 12)$ \\
\hline
\end{tabular}


416 1. Pecson, B. M.; Martin, L. V.; Kohn, T., Quantitative PCR for determining the infectivity 417 of bacteriophage MS2 upon inactivation by heat, UV-B radiation, and singlet oxygen: Advantages 418 and limitations of an enzymatic treatment to reduce false-positive results. Applied and 419 Environmental Microbiology 2009, 75, (17), 5544-5554.

420 2. APHA; AWWA; WEF, Standard Methods for the Examination of Water \& Wastewater. 421 21st Edition ed.; American Public Health Association, American Water Works Association and 422 Water Environment Federation: Washington, D.C., 2005.

423 3. Dunkin, N.; Weng, S.; Schwab, K. J.; McQuarrie, J.; Bell, K.; Jacangelo, J. G., 424 Comparative inactivation of murine norovirus and MS2 bacteriophage by peracetic acid and 425 monochloramine in municipal secondary wastewater effluent. Environmental Science \& 426 Technology 2017, 51, (5), 2972-2981.

427 4. Kim, J. Y.; Lee, C.; Sedlak, D. L.; Yoon, J.; Nelson, K. L., Inactivation of MS2 coliphage 428 by Fenton's reagent. Water Research 2010, 44, (8), 2647-2653.

429 5. Darling, A. J.; Boose, J. A.; Spaltro, J., Virus assay methods: Accuracy and validation. 430 Biologicals 1998, 26, (2), 105-110.

$431 \quad 6 . \quad$ Shi, C. J.; Wei, J.; Jin, Y.; Kniel, K. E.; Chiu, P. C., Removal of viruses and bacteriophages 432 from drinking water using zero-valent iron. Separation and Purification Technology 2012, 84, 7243378.

434 7. Brie, A.; Gantzer, C.; Boudaud, N.; Bertrand, I., The impact of chlorine and heat on the 435 infectivity and physicochemical properties of bacteriophage MS2. FEMS Microbiology Ecology 436 2018, 94, (8).

$437 \quad 8 . \quad$ You, Y.; Han, J.; Chiu, P. C.; Jin, Y., Removal and inactivation of waterborne viruses using 438 zerovalent iron. Environmental Science \& Technology 2005, 39, (23), 9263-9269.

439 9. Tanneru, C. T.; Chellam, S., Mechanisms of virus control during iron electrocoagulation440 microfiltration of surface water. Water Research 2012, 46, (7), 2111-2120.

441 10. Tanneru, C. T.; Rimer, J. D.; Chellam, S., Sweep flocculation and adsorption of viruses on 442 aluminum flocs during electrochemical treatment prior to surface water microfiltration. 443 Environmental Science \& Technology 2013, 47, (9), 4612-4618. 
444 11. Tanneru, C. T.; Jothikumar, N.; Hill, V. R.; Chellam, S., Relative insignificance of virus 445 inactivation during aluminum electrocoagulation of saline waters. Environmental Science \& 446 Technology 2014, 48, (24), 14590-14598.

447 12. Heffron, J.; Ryan, D. R.; Mayer, B. K., Sequential electrocoagulation-electrooxidation for 448 virus mitigation in drinking water. Water Research 2019, 160, 435-444.

449 13. Bicudo, B.; van Halem, D.; Trikannad, S. A.; Ferrero, G.; Medema, G., Low voltage iron 450 electrocoagulation as a tertiary treatment of municipal wastewater: removal of enteric pathogen 451 indicators and antibiotic-resistant bacteria. Water Research 2021, 188, 116500.

452 14. Heffron, J.; McDermid, B.; Maher, E.; McNamara, P. J.; Mayer, B. K., Mechanisms of 453 virus mitigation and suitability of bacteriophages as surrogates in drinking water treatment by iron 454 electrocoagulation. Water Research 2019, 163, 114877.

455 15. Delaire, C.; van Genuchten, C. M.; Nelson, K. L.; Amrose, S. E.; Gadgil, A. J., Escherichia 456 coli attenuation by $\mathrm{Fe}$ electrocoagulation in synthetic Bengal groundwater: Effect of $\mathrm{pH}$ and 457 natural organic matter. Environmental Science \& Technology 2015, 49, (16), 9945-9953.

458 16. Delaire, C.; van Genuchten, C. M.; Amrose, S. E.; Gadgil, A. J., Bacteria attenuation by 459 iron electrocoagulation governed by interactions between bacterial phosphate groups and Fe(III) 460 precipitates. Water Research 2016, 103, 74-82.

461 17. Chen, M.; Dollar, O.; Shafer-Peltier, K.; Randtke, S.; Waseem, S.; Peltier, E., Boron 462 removal by electrocoagulation: Removal mechanism, adsorption models and factors influencing 463 removal. Water Research 2020, 170, 115362.

464 18. Isa, M. H.; Ezechi, E. H.; Ahmed, Z.; Magram, S. F.; Kutty, S. R., Boron removal by 465 electrocoagulation and recovery. Water Research 2014, 51, 113-123.

466 19. Durante, C.; Cuscov, M.; Isse, A. A.; Sandona, G.; Gennaro, A., Advanced oxidation 467 processes coupled with electrocoagulation for the exhaustive abatement of Cr-EDTA. Water 468 Research 2011, 45, (5), 2122-2130.

469 20. Pan, C.; Troyer, L. D.; Catalano, J. G.; Giammar, D. E., Dynamics of chromium(VI) 470 removal from drinking water by iron electrocoagulation. Environmental Science \& Technology 471 2016, 50, (24), 13502-13510.

472 21. Pan, C.; Troyer, L. D.; Liao, P.; Catalano, J. G.; Li, W.; Giammar, D. E., Effect of humic 473 acid on the removal of chromium(VI) and the production of solids in iron electrocoagulation. 474 Environmental Science \& Technology 2017, 51, (11), 6308-6318. 
475 22. Li, L.; van Genuchten, C. M.; Addy, S. E.; Yao, J.; Gao, N.; Gadgil, A. J., Modeling As(III)

476 oxidation and removal with iron electrocoagulation in groundwater. Environmental Science \& 477 Technology 2012, 46, (21), 12038-12045.

478 23. Bandaru, S. R. S.; van Genuchten, C. M.; Kumar, A.; Glade, S.; Hernandez, D.; Nahata, 479 M.; Gadgil, A., Rapid and Efficient Arsenic Removal by Iron Electrocoagulation Enabled with in 480 Situ Generation of Hydrogen Peroxide. Environmental Science \& Technology 2020, 54, (10), $481 \quad 6094-6103$.

482 24. van Genuchten, C. M.; Addy, S. E.; Pena, J.; Gadgil, A. J., Removing arsenic from 483 synthetic groundwater with iron electrocoagulation: an Fe and As K-edge EXAFS study. 484 Environmental Science \& Technology 2012, 46, (2), 986-994.

485 25. Bandaru, S. R. S.; Roy, A.; Gadgil, A. J.; van Genuchten, C. M., Long-term electrode 486 behavior during treatment of arsenic contaminated groundwater by a pilot-scale iron 487 electrocoagulation system. Water Research 2020, 175, 115668.

488 26. Roy, M.; van Genuchten, C. M.; Rietveld, L.; van Halem, D., Integrating biological As(III) 489 oxidation with $\mathrm{Fe}(0)$ electrocoagulation for arsenic removal from groundwater. Water Research 490 2021, 188, 116531.

491 27. Wan, W.; Pepping, T. J.; Banerji, T.; Chaudhari, S.; Giammar, D. E., Effects of water 492 chemistry on arsenic removal from drinking water by electrocoagulation. Water Research 2011, 493 45, (1), 384-392.

494 28. Li, P.; Zhun, B.; Wang, X.; Liao, P.; Wang, G.; Wang, L.; Guo, Y.; Zhang, W., Highly 495 efficient interception and precipitation of uranium(VI) from aqueous solution by iron496 electrocoagulation combined with cooperative chelation by organic ligands. Environmental 497 Science \& Technology 2017, 51, (24), 14368-14378.

498 29. Dubrawski, K. L.; Mohseni, M., Standardizing electrocoagulation reactor design: Iron 499 electrodes for NOM removal. Chemosphere 2013, 91, (1), 55-60.

500 30. McBeath, S. T.; Nouri-Khorasani, A.; Mohseni, M.; Wilkinson, D. P., In-situ determination 501 of current density distribution and fluid modeling of an electrocoagulation process and its effects 502 on natural organic matter removal for drinking water treatment. Water Research 2020, 171, 503115404. 
504 31. Dubrawski, K. L.; Mohseni, M., In-situ identification of iron electrocoagulation speciation 505 and application for natural organic matter (NOM) removal. Water Research 2013, 47, (14), 53715065380.

507 32. Devlin, T. R.; di Biase, A.; Wei, V.; Elektorowicz, M.; Oleszkiewicz, J. A., Removal of 508 soluble phosphorus from surface water using iron (Fe-Fe) and aluminum (Al-Al) electrodes. 509 Environmental Science \& Technology 2017, 51, (23), 13825-13833.

510 33. Tian, Y.; He, W.; Liang, D.; Yang, W.; Logan, B. E.; Ren, N., Effective phosphate removal 511 for advanced water treatment using low energy, migration electric-field assisted electrocoagulation. $512 \quad$ Water Research 2018, 138, 129-136.

513 34. Liang, S.; Zheng, W.; Zhu, L.; Duan, W.; Wei, C.; Feng, C., One-step treatment of 514 phosphite-laden wastewater: A single electrochemical reactor integrating superoxide radical515 induced oxidation and electrocoagulation. Environmental Science \& Technology 2019, 53, (9), $516 \quad 5328-5336$.

517 35. Cañizares, P.; Martínez, F.; Jiménez, C.; Lobato, J.; Rodrigo, M. A., Coagulation and 518 electrocoagulation of wastes polluted with dyes. Environmental Science \& Technology 2006, 40, 519 (20), 6418-6424.

520 36. Bocos, E.; Brillas, E.; Sanroman, M. A.; Sires, I., Electrocoagulation: Simply a phase 521 separation Technology? The case of bronopol compared to its treatment by EAOPs. Environmental 522 Science \& Technology 2016, 50, (14), 7679-7686.

523 37. Lin, H.; Wang, Y.; Niu, J.; Yue, Z.; Huang, Q., Efficient sorption and removal of 524 perfluoroalkyl acids (PFAAs) from aqueous solution by metal hydroxides generated in situ by 525 electrocoagulation. Environmental Science \& Technology 2015, 49, (17), 10562-10569.

526 38. Ryan, D. R.; McNamara, P. J.; Mayer, B. K., Iron-electrocoagulation as a disinfection 527 byproduct control strategy for drinking water treatment. Environmental Science: Water Research 528 \& Technology 2020, 6, (4), 1116-1124.

529 39. Lakshmanan, D.; Clifford, D. A.; Samanta, G., Ferrous and ferric ion generation during 530 iron electrocoagulation. Environmental Science \& Technology 2009, 43, (10), 3853-3859.

531 40. Kreißel, K.; Bosl, M.; Hugler, M.; Lipp, P.; Franzreb, M.; Hambsch, B., Inactivation of F532 specific bacteriophages during flocculation with polyaluminum chloride - A mechanistic study. 533 Water Research 2014, 51, 144-151. 
534 41. Zhu, B.; Clifford, D. A.; Chellam, S., Virus removal by iron coagulation-microfiltration. 535 Water Research 2005, 39, (20), 5153-5161.

536 42. Bagga, A.; Chellam, S.; Clifford, D. A., Evaluation of iron chemical coagulation and 537 electrocoagulation pretreatment for surface water microfiltration. Journal of Membrane Science $538 \quad 2008,309,(1-2), 82-93$.

539 43. Kim, J. Y.; Lee, C.; Love, D. C.; Sedlak, D. L.; Yoon, J.; Nelson, K. L., Inactivation of 540 MS2 coliphage by ferrous ion and zero-valent iron nanoparticles. Environmental Science \& 541 Technology 2011, 45, (16), 6978-6984.

542 44. Baga, A. N.; Johnson, G. R. A.; Nazhat, N. B.; Saadallanazhat, R. A., A simple 543 spectrophotometric determination of hydrogen-peroxide at low concentrations in aqueous solution. 544 Analytica Chimica Acta 1988, 204, (1-2), 349-353.

545 45. Kosaka, K.; Yamada, H.; Matsui, S.; Echigo, S.; Shishida, K., Comparison among the 546 methods for hydrogen peroxide measurements to evaluate advanced oxidation processes: 547 Application of a spectrophotometric method using copper(II) ion and 2.9 dimethyl-1,10548 phenanthroline. Environmental Science \& Technology 1998, 32, (23), 3821-3824.

549 46. Smith, G. F.; Mccurdy, W. H., 2,9-Dimethyl-1,10-phenanthroline - New specific in 550 spectrophotometric determination of copper. Analytical Chemistry 1952, 24, (2), 371-373.

551 47. Mariey, L.; Signolle, J. P.; Amiel, C.; Travert, J., Discrimination, classification, 552 identification of microorganisms using FTIR spectroscopy and chemometrics. Vibrational 553 Spectroscopy 2001, 26, (2), 151-159.

554 48. Goeller, L. J.; Riley, M. R., Discrimination of bacteria and bacteriophages by Raman 555 spectroscopy and surface-enhanced Raman spectroscopy. Applied Spectroscopy 2007, 61, (7), 556 679-685.

557 49. Vargas, C. A.; Wilhelm, A. A.; Williams, J.; Lucas, P.; Reynolds, K. A.; Riley, M. R., 558 Integrated capture and spectroscopic detection of viruses. Applied and Environmental 559 Microbiology 2009, 75, (20), 6431-6440.

560 50. Hill, V. R.; Kahler, A. M.; Jothikumar, N.; Johnson, T. B.; Hahn, D.; Cromeans, T. L., 561 Multistate evaluation of an ultrafiltration-based procedure for simultaneous recovery of enteric 562 microbes in 100-liter tap water samples. Applied and Environmental Microbiology 2007, 73, (13), $563 \quad 4218-4225$. 
564 51. Connell, K. P.; Bucher, J. R.; Anderson, P. E.; Cao, C. J.; Khan, A. S.; Gostomski, M. V.; 565 Valdes, J. J., Real-time fluorogenic reverse transcription-PCR assays for detection of 566 bacteriophage MS2. Applied and Environmental Microbiology 2006, 72, (1), 478-483.

567 52. Johnson, I.; Spence, M. T. Z., The molecular probes handbook. A guide to fluorescent 568 probes and labeling technologies. 11 ed.; Invitrogen Corp: Carlsbad, CA, 2010.

569 53. Chen, N.-d.; Chen, H.; Li, J.; Sang, M.-m.; Ding, S.; Yu, H., Discrimination and similarity 570 evaluation of tissue-cultured and wild Dendrobium species using Fourier transform infrared 571 spectroscopy. Journal of Molecular Structure 2015, 1086, 255-265.

572 54. Jiang, Y.; Li, C.; Nguyen, X.; Muzammil, S.; Towers, E.; Gabrielson, J.; Narhi, L., 573 Qualification of FTIR spectroscopic method for protein secondary structural analysis. Journal of 574 Pharmaceutical Sciences 2011, 100, (11), 4631-4641.

575 55. Barth, A., Infrared Spectroscopy of Proteins. Biochimica et Biophysica Acta 2007, 1767, 576 (9), 1073-1101.

577 56. Jackson, M.; Mantsch, H. H., The use and misuse of FTIR spectroscopy in the 578 determination of protein structure. Critical Reviews in Biochemistry and Molecular Biology 1995, $57930,(2), 95-120$.

580 57. Stuart, B., Infrared Spectroscopy: Fundamentals and Applications. John Wiley \& Sons, $581 \quad$ Ltd.: 2004.

582 58. Siebert, F., [20] Infrared spectroscopy applied to biochemical and biological problems. In 583 Methods in Enzymology, Academic Press: 1995; Vol. 246, pp 501-526.

584 59. Elliott, A.; Ambrose, E. J., Structure of synthetic polypeptides. Nature 1950, 165, (4206), $585921-922$.

586 60. Surewicz, W. K.; Mantsch, H. H., New insight into protein secondary structure from 587 resolution-enhanced infrared spectra. Biochimica et Biophysica Acta (BBA) - Protein Structure 588 and Molecular Enzymology 1988, 952, 115-130.

589 61. Movasaghi, Z.; Rehman, S.; Rehman, I. U., Fourier transform infrared (FTIR) spectroscopy 590 of biological tissues. Applied Spectroscopy Reviews 2008, 43, (2), 134-179.

591 62. Barth, A., The infrared absorption of amino acid side chains. Progress in Biophysics and 592 Molecular Biology 2000, 74, (3-5), 141-173.

593 63. Dovbeshko, G. I.; Gridina, N. Y.; Kruglova, E. B.; Pashchuk, O. P., FTIR spectroscopy 594 studies of nucleic acid damage. Talanta 2000, 53, (1), 233-246. 
64. Theis, T. L.; Singer, P. C., Complexation of iron(11) by organic matter and its effect on iron(1l) oxygenation. Environmental Science \& Technology 1974, 8, (6), 569-573.

65. Stumm, W.; Lee, G. F., Oxygenation of ferrous iron. Industrial and Engineering Chemistry 1961, 53, (2), 143-146.

66. Bataineh, H.; Pestovsky, O.; Bakac, A., pH-induced mechanistic changeover from hydroxyl radicals to iron(IV) in the Fenton reaction. Chemical Science 2012, 3, (5), 1594-1599.

67. Adewuyl, Y. G.; Carmlchae, G. R., Kinetics of oxidation of dimethyl sulfide by hydrogen peroxide in acidic and alkaline medium. Environmental Science \& Technology 1986, 20, 10171022.

68. Nieto-Juarez, J. I.; Pierzchla, K.; Sienkiewicz, A.; Kohn, T., Inactivation of MS2 coliphage in Fenton and Fenton-like systems: Role of transition metals, hydrogen peroxide and sunlight. Environmental Science \& Technology 2010, 44, (9), 3351-3356.

69. Nahar, S.; Tajmirriahi, H. A., A comparative study of Fe(II) and Fe(III) ions complexation with proteins of the light-harvesting complex of chloroplast thylakoid membranes. Journal of Inorganic Biochemistry 1994, 54, (2), 79-90.

70. Kinsela, A. S.; Jones, A. M.; Bligh, M. W.; Pham, A. N.; Collins, R. N.; Harrison, J. J.; Wilsher, K. L.; Payne, T. E.; Waite, T. D., Influence of dissolved silicate on rates of Fe(II) oxidation. Environmental Science \& Technology 2016, 50, (21), 11663-11671.

71. Meneghini, R., Iron homeostasis, oxidative stress, and DNA damage. Free Radical Biology \& Medicine 1997, 23, (5), 783-792.

72. Loeb, S. K.; Jennings, W. C.; Wigginton, K. R.; Boehm, A. B., Sunlight inactivation of human norovirus and bacteriophage MS2 using a genome-wide PCR-based approach and enzyme pretreatment. Environmental Science \& Technology 2021, 55, (13), 8783-8792.

73. Leifels, M.; Cheng, D.; Sozzi, E.; Shoults, D. C.; Wuertz, S.; Mongkolsuk, S.; Sirikanchana, K., Capsid integrity quantitative PCR to determine virus infectivity in environmental and food applications - A systematic review. Water Research X 2021, 11, 100080.

74. Duizer, E.; Bijkerk, P.; Rockx, B.; De Groot, A.; Twisk, F.; Koopmans, M., Inactivation of caliciviruses. Applied and Environmental Microbiology 2004, 70, (8), 4538-4543.

75. Wiegand, H. L.; Orths, C. T.; Kerpen, K.; Lutze, H. V.; Schmidt, T. C., Investigation of the iron-peroxo complex in the Fenton reaction: Kinetic indication, decay kinetics, and hydroxyl radical yields. Environmental Science \& Technology 2017, 51, (24), 14321-14329. 
626 